\title{
Procyanidins Extracted from Lotus Seedpod Ameliorate Amyloid- $\beta$-Induced Toxicity in Rat Pheochromocytoma Cells
}

\author{
Hao Huang, ${ }^{1,2}$ Peipei Yan, ${ }^{3}$ Taoping Sun,,2 Xiaoxing Mo, ${ }^{1,2}$ Jiawei Yin,, ${ }^{1,2}$ Peiyun Li, ${ }^{1,2}$ \\ Yalun Zhu, ${ }^{1,2}$ Shuang Rong, ${ }^{4}$ Wei Yang, ${ }^{1,2}$ Xiaoyi Chen $\mathbb{D}^{5}{ }^{5}$ and Liegang Liu $\mathbb{D}^{1,2}$ \\ ${ }^{1}$ Department of Nutrition and Food Hygiene, Hubei Key Laboratory of Food Nutrition and Safety, Tongji Medical College, \\ Huazhong University of Science and Technology, Wuhan 430030, China \\ ${ }^{2}$ Ministry of Education Key Lab of Environment and Health, School of Public Health, Tongji Medical College, China \\ ${ }^{3}$ Chongqing Center for Disease Control and Prevention, Chongqing 400000, China \\ ${ }^{4}$ Department of Nutrition and Food Hygiene, School of Public Health, Medical College, Wuhan University of Science and Technology, \\ Wuhan 430065, China \\ ${ }^{5}$ School of Public Health, Guangzhou Medical University, Guangzhou 511436, China
}

Correspondence should be addressed to Xiaoyi Chen; wwchenxy1@163.com and Liegang Liu; lgliu@mails.tjmu.edu.cn

Received 30 March 2018; Revised 26 July 2018; Accepted 6 August 2018; Published 28 October 2018

Academic Editor: Felipe L. de Oliveira

Copyright (C) 2018 Hao Huang et al. This is an open access article distributed under the Creative Commons Attribution License, which permits unrestricted use, distribution, and reproduction in any medium, provided the original work is properly cited.

\begin{abstract}
Alzheimer's disease (AD) is a progressive neurodegenerative disease, which is characterized by extracellular senile plaque deposits, intracellular neurofibrillary tangles, and neuronal apoptosis. Amyloid- $\beta(\mathrm{A} \beta)$ plays a critical role in $\mathrm{AD}$ that may cause oxidative stress and downregulation of CREB/BDNF signaling. Anti-A $\beta$ effect has been discussed as a potential therapeutic strategy for AD. This study aimed to identify the amelioration of procyanidins extracted from lotus seedpod (LSPC) on A $\beta$-induced damage with associated pathways for AD treatment. Rat pheochromocytoma (PC12) cells incubated with $\mathrm{A} \beta_{25-35}$ serve as an $\mathrm{A} \beta$ damage model to evaluate the effect of LSPC in vitro. Our findings illustrated that LSPC maintained the cellular morphology from deformation and reduced apoptosis rates of cells induced by $\mathrm{A} \beta_{25-35}$. The mechanisms of LSPC to protect cells from A $\beta$-induced damage were based on its regulation of oxidation index and activation of CREB/BDNF signaling, including brain-derived neurotrophic factor (BDNF) and phosphorylation of cAMP-responsive element-binding (CREB), protein kinase B (also known as AKT), and the extracellular signal-regulated kinase (ERK). Of note, by high-performance liquid chromatography-tandem mass spectroscopy (LC-MS/MS), several metabolites were detected to accumulate in vivo, part of which could take primary responsibility for the amelioration of A $\beta$-induced damage on PC12 cells. Taken together, our research elucidated the effect of LSPC on neuroprotection through anti- $\mathrm{A} \beta$, indicating it as a potential pretreatment for Alzheimer's disease.
\end{abstract}

\section{Introduction}

Alzheimer's disease (AD), a progressive neurodegenerative disease, is characterized by extracellular senile plaque deposits, intracellular neurofibrillary tangles, and neuronal apoptosis. Progressive loss of memory and other cognitive functions are typical symptoms in $A D$ [1]. According to the amyloid hypothesis, amyloid- $\beta-(\mathrm{A} \beta-)$ related toxicity and imbalance are cardinal reasons that contribute to synaptic dysfunction and subsequent neurodegeneration in $\mathrm{AD}$ $[2,3]$. $A \beta$ has been, therefore, suggested as a potential therapeutic target for $\mathrm{AD}$ treatment [4].
As similar to other age-related diseases, exorbitant oxidative stress is the fundamental feature of $\mathrm{AD}$ since $\mathrm{A} \beta$ may lead to oxidative stress and macroautophagy [5]. Oxidative stress induced by $\mathrm{A} \beta$ may disorder the membrane ion function and glutamate transporters of synapses, resulting in their dysfunction and degeneration [5]. Antioxidant compounds hence may have a positive effect on the mitigation of $\mathrm{A} \beta$-induced damages. AKT (also known as protein kinase $\mathrm{B}$ ) and extracellular signal-regulated kinase (ERK) are two key kinases in modulating brain-derived neurotrophic factor (BDNF) transcription by activating phosphorylation of cAMP-responsive element-binding (CREB) $[6,7]$, both of 
which could be attenuated by $\mathrm{A} \beta[8,9]$. BDNF, a pivotal role in learning and memory $[10,11]$, is downregulated by $\mathrm{A} \beta$ in $\mathrm{AD}$ [12]. The underlying mechanism of $A \beta$ on $C R E B / B D N F$ signaling is possible that $A \beta$ inhibits the activation of $A K T$ and ERK, resulting in decreasing phosphorylation of CREB, the upstream of BDNF [13], and then, attenuating both transcriptions of BDNF mRNA and expression of BDNF protein [14]. Therefore, simulating CREB/BDNF signaling against $\mathrm{A} \beta$-induced damage is a promising therapeutic tactic for AD. CREB activators, BDNF imitators, or flavonoid-high dietary habit have been identified to ameliorate AD [15-17]. BDNF and oxidative stress also have an interactive influence in vivo $[18,19]$ so nature compounds are beneficial for $\mathrm{AD}$ treatment, which can modulate oxidative stress and CREB/BDNF signaling.

Lotus has been usually used as a Chinese traditional medicine, including its leaf, embryo loti, and seedpod [20, 21]. Procyanidins, as flavonoids, are highly correlated to learning and memory improvement $[22,23]$ and exhibit the potential for $\mathrm{AD}$ treatment $[16,24]$. Procyanidins extracted from the lotus seedpod (LSPC) is the fresh and abundant resource of flavonoids [25]. In age-related mice, LSPC has been reported to enhance the abilities of learning and memory [26, 27]. Consequently, we put forward the assumption that LSPC might display the property of anti- $\mathrm{A} \beta$ in $\mathrm{AD}$ while there was no definitive evidence for its anti-A $\beta$ toxicity function and its main pathways. LSPC, as a complex mixture, is composed of oligomeric procyanidins and polymeric procyanidins such as epicatechin, procyanidins dimers, and quercetin glucuronide [25] while it was insufficient in research exploring its distribution in vivo, which might be conducive to expound its impact.

In this study, we aimed to verify its anti-A $\beta$ effects and protective mechanisms as a promising nature production for $\mathrm{AD}$ treatment. We evaluated amelioration of LSPC in $\mathrm{A} \beta_{25-35}$-induced damage on rat pheochromocytoma (PC12) cells. CREB/BDNF signaling and antioxidant activity were studied as possible pathways. We used LC-MS/MS to analyze its distribution in vivo.

\section{Materials and Methods}

2.1. Cells and Reagents. PC12 cells were from Tongji Medical College, Huazhong Science and Technology University. LSPC was provided by Huazhong Agriculture University (China). Cell Counting Kit-8 (CCK-8) was purchased from Dojindo (Japan); anti-BDNF antibody was purchased from Elabscience (China); anti-CREB antibody, anti-phospho-CREB (Ser ${ }^{133}$ ) antibody, anti-AKT antibody, anti-phospho-AKT (Ser ${ }^{473}$ ) antibody, anti-ERK1/2 antibody, anti-phospho-ERK1/2 (Thr202/Tyr ${ }^{204}$ ) antibody, and anti-GAPDH antibody were purchased from cell signaling; LY294002 inhibitor for PI3K and PD98059 inhibitor for ERK1/2 were purchased from Selleckchem; lactate dehydrogenase (LDH), superoxide dismutase (SOD), and malonialdehyde (MDA) were from Nanjing Jiancheng Bioengineering Institute (Nanjing, China); gallic acid was purchased from DRE; procyanidin dimer B (PDB) was purchased from Fluka Co.; epigallocatechin gallate (ECG) was purchased from
Chromadex; Annexin V-FITC for flow cytometry was purchased from BestBio; Hoechst staining for apoptosis analysis, BCA protein assay kit, and RIPA lysis solution was purchased from Beyotime; all other reagents were purchased from Sigma.

2.2. Cells Culture and Dosages of $A \beta_{25-35}$ and LSPC. PC12 cells were cultured in Roswell Park Memorial Institute (RPMI) 1640 medium with 10\% fetal bovine serum in an atmosphere containing $5 \% \quad \mathrm{CO}_{2}$ at $37^{\circ} \mathrm{C}$. To decide an intervention dose of $\mathrm{A} \beta_{25-35}$, we added different doses of $\mathrm{A} \beta_{25-35}(0,5,10,20$, and $40 \mu \mathrm{M})$ into cells and incubated for six periods of time $(6,12,24,48$, and $72 \mathrm{~h})$, respectively. $\mathrm{A} \beta_{25-35}$ was prepared by dissolved in sterile PBS and aggregated through incubation at $37^{\circ} \mathrm{C}$ for 4 days. In order to choose an intervention dose of LSPC, we added six dosages of $\operatorname{LSPC}(1,2.5,5,10,20$, and $40 \mu \mathrm{g} / \mathrm{mL})$ into 96 -well plates 30 minutes before incubation with $\mathrm{A} \beta_{25-35}$ for $24 \mathrm{~h}$ or without $\mathrm{A} \beta_{25-35}$ for $24 \mathrm{~h}$. Dosages for both $\mathrm{A} \beta_{25-35}$ and LSPC were determined through measuring cell viability by CCK- 8 according to the instruction. In brief, $10 \mu \mathrm{L}$ CCK- 8 was added to each sample $(100 \mu \mathrm{L})$ with $2 \mathrm{~h}$ incubation under $37^{\circ} \mathrm{C}$, and absorbance value of each sample was measured by an enzyme immunoassay analyzer (Bio-Tek, USA) at $570 \mathrm{~nm}$.

2.3. PC12 Cells Imaging. After determination of $\mathrm{A} \beta_{25-35}$ and LSPC doses, cells were cultured as three groups (PC12 cells, PC12 cells with $20 \mu \mathrm{M} \mathrm{A} \beta_{25-35}$, and PC12 cells with $20 \mu \mathrm{M}$ $\mathrm{A} \beta_{25-35}$ and $10 \mu \mathrm{g} / \mathrm{mL}$ LSPC), which were seeded on 6 -well plates at a density of $1 \times 10^{6}$ cells $/ \mathrm{mL}$. Cells after treatment were fixed by paraformaldehyde and observed morphology under a microscope (Olympus Corporation, Japan).

2.4. Hoechst Staining. Cells were seeded on 6-well plates. After intervention as three groups, each group was washed with PBS twice before $800 \mu \mathrm{L}$ staining buffer was added and subsequently stained with Hoechst staining solution $(5 \mu \mathrm{L})$ for $30 \mathrm{~min}$ in the dark. Cells were imaged on a fluorescence microscope (Olympus Corporation, Japan). Hoechst staining was executed according to the instructions (Beyotime, China).

2.5. Flow Cytometry. Cells seeded on 6-well plates were washed with cold PBS twice. The number of cells was kept closing to $1 \times 10^{6} / \mathrm{mL}$ in each sample and $400 \mu \mathrm{L} 1 \times$ Annexin $\mathrm{V}$ was provided. Each sample was incubated with $5 \mu \mathrm{L}$ Annexin $\mathrm{V}$-FITC staining for $5 \mathrm{~min}$ at $4^{\circ} \mathrm{C}$. Then $10 \mu \mathrm{L}$ propidium iodide (PI) staining was added for $5 \mathrm{~min}$ at $4^{\circ} \mathrm{C}$. Samples were detected by a flow cytometry (Becton Dickinson, USA) and analyzed by FlowJo software (version 7.6). All procedures were consistent with the instructions (BestBio, China). Cells containing Annexin V-positive staining merely were defined to be in early apoptosis (EA), whereas cells stained with both Annexin V and PI were defined to be in late apoptosis (LA). Total apoptosis (TA) consisted of EA and LA.

2.6. Determination of Antioxidant Activity. Cells were divided into six groups (PC12 cells, PC12 cells with $20 \mu \mathrm{M}$ $\mathrm{A} \beta_{25-35}$, PC12 cells with $20 \mu \mathrm{M} \mathrm{A} \beta_{25-35}$ and $5 \mu \mathrm{g} / \mathrm{mL}$ LSPC, 


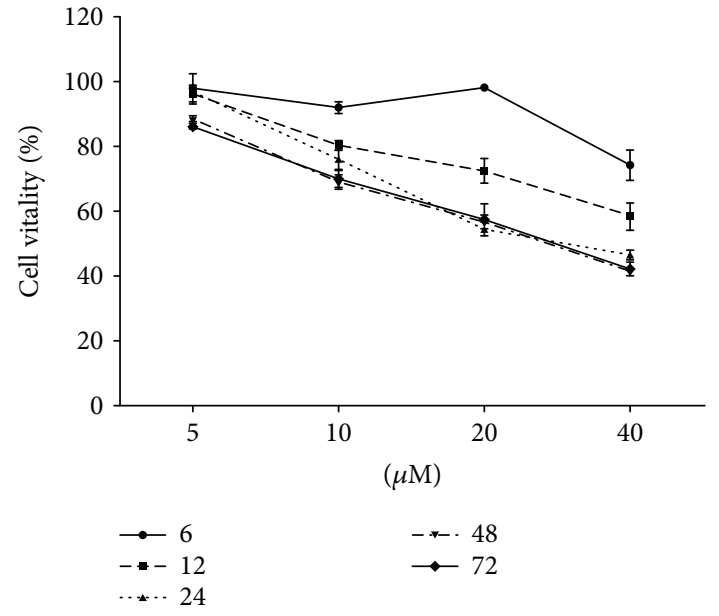

(a)

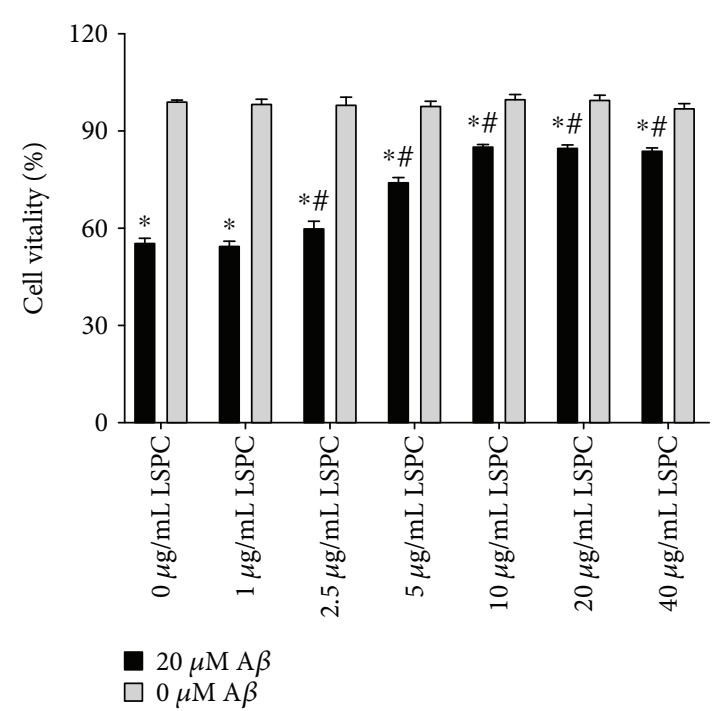

(b)

FIgURE 1: Determination for both $\mathrm{A} \beta_{25-35}$ and LSPC through measuring survival rates of cells by CCK-8. (a) Survival rate of cells under variable dosage of $\mathrm{A} \beta_{25-35}$ with different intervene time $(\overline{\mathrm{x}} \pm$ SEM, $n=6, \%)$. (b) Survival rates of cells under different dosages of LSPC with $20 \mu \mathrm{M} \mathrm{A} \beta_{25-35}$ (black) and without $\mathrm{A} \beta_{25-35}$ (gray) ( $\left.\mathrm{x} \pm \mathrm{SEM}, n=6, \%\right) .0 \mu \mathrm{g} / \mathrm{mL}$ LSPC, PC12 cells with $20 \mu \mathrm{M} \mathrm{A} \beta_{25-35}$ group, and without $\mathrm{A} \beta_{25-35} ; 1 \mu \mathrm{g} / \mathrm{mL}$ LSPC, PC12 cells with $1 \mu \mathrm{g} / \mathrm{mL}$ LSPC for 30 minutes before incubation with $20 \mu \mathrm{M}$ A $\beta_{25-35}$ group, and without $\mathrm{A} \beta_{25-35} ; 2.5 \mu \mathrm{g} / \mathrm{mL}$ LSPC, PC12 cells with $2.5 \mu \mathrm{g} / \mathrm{mL}$ LSPC for 30 minutes before incubation with $20 \mu \mathrm{M}$ A $\beta_{25-35}$ group, and without $\mathrm{A} \beta_{25-35} ; 5 \mu \mathrm{g} / \mathrm{mL}$ LSPC, PC12 cells with $5 \mu \mathrm{g} / \mathrm{mL}$ LSPC for 30 minutes before incubation with $20 \mu \mathrm{M} \mathrm{A} \beta_{25-35}$ group, and without $\mathrm{A} \beta_{25-35}$; $10 \mu \mathrm{g} / \mathrm{mL}$ LSPC, PC12 cells with $10 \mu \mathrm{g} / \mathrm{mL}$ LSPC for 30 minutes before incubation with $20 \mu \mathrm{M} \mathrm{A} \beta_{25-35}$ group, and without $\mathrm{A} \beta_{25-35}$; $20 \mu \mathrm{g} / \mathrm{mL}$ LSPC, PC12 cells with $20 \mu \mathrm{g} / \mathrm{mL}$ LSPC for 30 minutes before incubation with $20 \mu \mathrm{M} \mathrm{A} \beta_{25-35}$ group and without $\mathrm{A} \beta_{25-35}$; $40 \mu \mathrm{g} / \mathrm{mL}$ LSPC, PC12 cells with $40 \mu \mathrm{g} / \mathrm{mL}$ LSPC for 30 minutes before incubation with $20 \mu \mathrm{M} \mathrm{A} \beta_{25-35}$ group and without $\mathrm{A} \beta_{25-35}$; ${ }^{*} P<0.05$ for groups vs PC12 cells without $\mathrm{A} \beta_{25-35}$ and LSPC; ${ }^{\#} P<0.05$ for groups vs PC12 cells with A $\beta_{25-35}$ but without LSPC. All the results above are the representative of the three independent experiments.

PC12 cells with $20 \mu \mathrm{M} \mathrm{A} \beta_{25-35}$ and $10 \mu \mathrm{g} / \mathrm{mL}$ LSPC, and PC12 cells with $20 \mu \mathrm{M} \mathrm{A} \beta_{25-35}$ and $20 \mu \mathrm{g} / \mathrm{mL}$ LSPC). The levels of LDH, T-SOD, and MDA were measured depending on the methods [28] and instructions recommended by Nanjing Jiancheng Bioengineering Institute (Nanjing, China). $\mathrm{LDH}$ activity of each sample was detected by an enzyme immunoassay analyzer (Bio-Tek, USA) at $450 \mathrm{~nm}$, and the values were expressed as units per liter. For T-SOD, a BCA protein assay kit (Beyotime, China) was applied to determine the values of proteins expression. The absorbance value of each sample was measured at $570 \mathrm{~nm}$, and the values of T-SOD activity was calculated as units per $\mathrm{mg}$ protein. Quantification of MDA was stated as nanomoles per mg protein by testing absorbance values at $532 \mathrm{~nm}$.

2.7. Western Blot. Cells were cultured as seven groups (PC12 cells, PC12 cells with $20 \mu \mathrm{M} \mathrm{A} \beta_{25-35}$, PC12 cells added with $10 \mu \mathrm{g} / \mathrm{mL}$ LSPC 30 minutes before incubation with $20 \mu \mathrm{M} \mathrm{A} \beta_{25-35}$, PC12 cells with $10 \mu \mathrm{M}$ LY294002, PC12 cells added $10 \mu \mathrm{g} / \mathrm{mL}$ LSPC 30 minutes before incubation with $10 \mu \mathrm{M}$ LY294002, PC12 cells with $30 \mu \mathrm{M}$ PD98059, and PC12 cells added with $10 \mu \mathrm{g} / \mathrm{mL}$ LSPC 30 minutes before incubation with $30 \mu \mathrm{M}$ PD98059). After intervention, cells were washed three times using cold PBS. After centrifugation $(14000 \times \mathrm{rpm}, 5 \mathrm{~min})$, each sample was collected excluding the supernatant and lysed in $300 \mu \mathrm{L}$ lysis buffer for $2 \mathrm{~h}$, following centrifugation for $10 \mathrm{~min}$ at $14000 \times \mathrm{rpm}$. The proteins in the supernatant were quantified using the BCA method as above. For blot analysis, samples $(20 \mu \mathrm{L}$, each) were boiled, separated on $7.5 \%-12 \%$ SDS-PAGE, and transferred to polyvinylidene difluoride (PVDF) membranes. The membranes were hybridized with various antibodies overnight at $4^{\circ} \mathrm{C}$, including anti-BDNF antibody (1:1000), anti-CREB antibody $(1: 1000)$, anti-phosphoCREB (Ser ${ }^{133}$ ) antibody (1:1000), anti-AKT antibody (1:1000), anti-phospho-AKT $\left(\mathrm{Ser}^{473}\right)$ antibody $(1: 1000)$, anti-ERK1/2 antibody $(1: 1000)$, anti-phospho-ERK1/2 (Thr202/Tyr $\left.{ }^{204}\right)$ antibody $(1: 1000)$, and anti-GAPDH antibody $(1: 3000)$ as internal standard and then incubated with secondary antibodies for $1 \mathrm{~h}$ at room temperature. The images were obtained through a Fluorescence Chemical Imaging Analysis System (Syngene, British). The intensities of the bands were analyzed by the ImageJ software.

2.8. Quantitative Real-Time PCR ( $q R T-P C R)$. Total RNA was isolated from cells via RNAiso Plus (TaKaRa, China), and cRNA was extracted using the PrimeScript ${ }^{\mathrm{TM}}$ RT reagent Kit (TaKaRa, China), all of which were based on the instructions. qRT-PCR was carried out using the SYBR ${ }^{\circledR}$ Premix $E x T^{T} q^{\mathrm{TM}}$ (TaKaRa, China) with an ABI 7900HT real-time thermocycler (Applied Biosystems, CA), as previously described [29]. The correlated expressions of genes were calculated by $2^{-\triangle \triangle \mathrm{CT}}$ methods. Primers of specific genes, including BDNF (forward: $5^{\prime}$-AGCAGGCTCTGGAATGATGT-3'; reverse: $\quad 5^{\prime}$-GGATTTGAGTGTGGTTCTCCA-3') and 


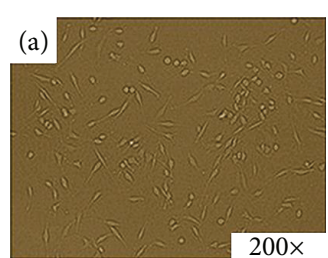

(a)

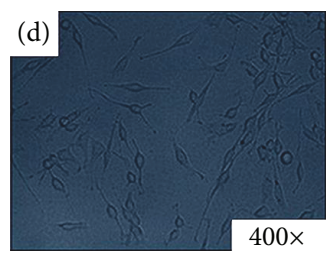

(d)

Control
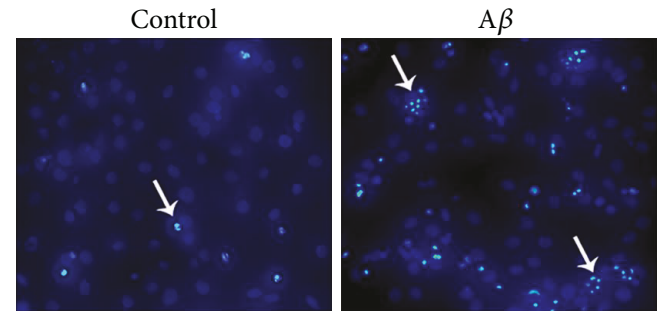

(g)

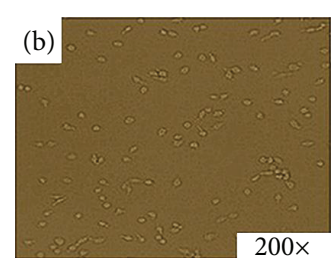

(b)

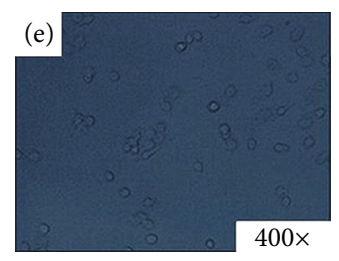

(e)
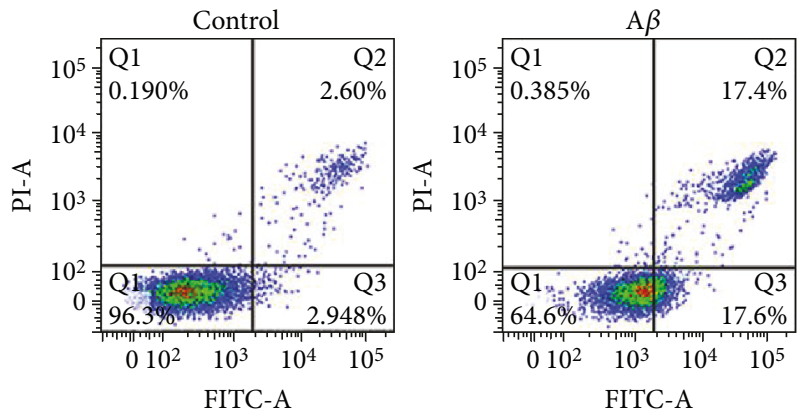

(h)

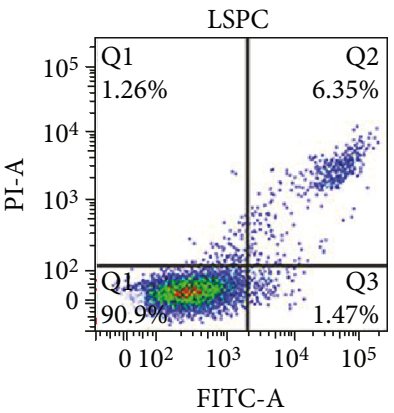

FITC-A

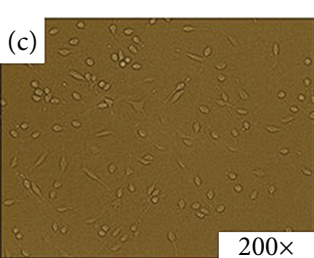

(c)

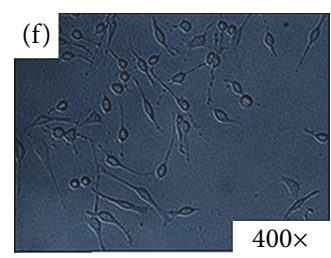

(f)

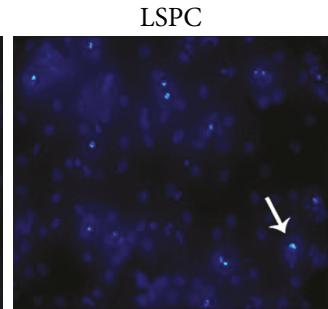

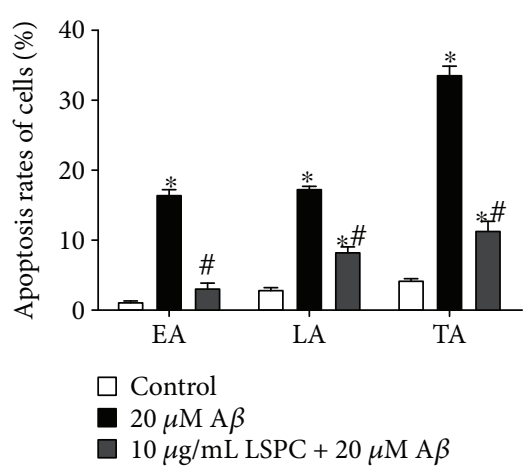

(i)

FIgURE 2: The effect of LSPC against $\mathrm{A} \beta_{25-35}$-induced apoptosis on PC12 cells. (a-f) Cellular morphology of different groups under an

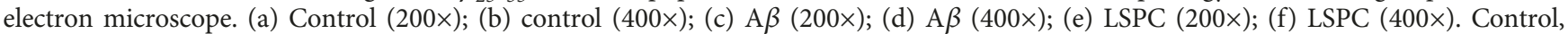
PC1 2 cells; A $\beta$, PC12 cells with $20 \mu \mathrm{M} \mathrm{A} \beta_{25-35}$; LSPC, PC12 cells added into $10 \mu \mathrm{g} / \mathrm{mL}$ LSPC 30 minutes before incubation with $20 \mu \mathrm{M}$ $\mathrm{A} \beta_{25-35}$. In the electron microscope, PC12 cells with $10 \mu \mathrm{g} / \mathrm{mL}$ LSPC and $20 \mu \mathrm{M} \mathrm{A} \beta_{25-35}(\mathrm{e}, \mathrm{f})$ showed the approximate number of cells and identical cellular morphology as a control group (a,b), while A $\beta$ group (c, d) illustrated the reduction of cells number and abnormal morphology. (g) Hoechst staining reflects the apoptosis of cells in each group; apoptosis cells are pointed out by white arrows. (h and i) Flow cytometry calculates apoptosis rates of different groups after Annexin V/PI staining. Apoptosis rate of each group are mean \pm SEM; ${ }^{*} \mathrm{P}<0.05$ for groups vs control; ${ }^{\#} P<0.05$ for groups vs $\mathrm{A} \beta_{25-35}$ group. Control, PC12 cells; A $\beta$, PC12 cells with $20 \mu \mathrm{M}$ A $\beta_{25-35}$; LSPC, PC1 2 cells added into $10 \mu \mathrm{g} / \mathrm{mL}$ LSPC 30 minutes before incubation with $20 \mu \mathrm{M} \mathrm{A} \beta_{25-35}$. All the results above are the representative of the three independent experiments run in quadruplicate.

GAPDH (forward: $5^{\prime}$-GCCCAGCAAGGATACTGAGA-3'; reverse: $5^{\prime}$-GGATGGAATTGTGAGGGAGA-3') as control, were synthesized by Sangon Corp. (Sangon Biotech Co., Ltd., China).

2.9. Animals. Fourteen male Sprague-Dawley rats $(226 \pm 35 \mathrm{~g}$, obtained from the Experimental Animal Center of Tongji Medical College, Huazhong Science and Technology University) with two or three per cage were kept in a controlled temperature $\left(23 \pm 1^{\circ} \mathrm{C}\right)$ under a $12 \mathrm{~h}$ dark-light cycle. All rats were free access to deionized water and diet for 1 week. All procedures were in accordance with the guidelines of Tongji Medical College Council on Animal Care Committee, Huazhong Science and Technology University (IACUC number: S407, approval date was 28 March 2015).

2.10. LSPC Treatment. Prior to administration of LSPC, rats were randomly divided into two groups ( $n=7$ per group) 


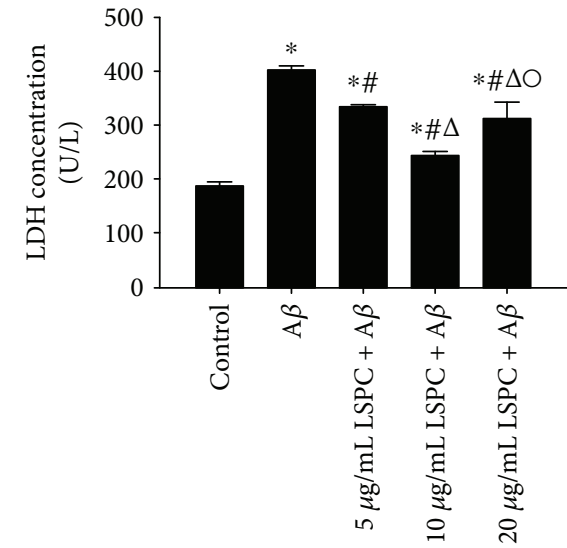

(a)

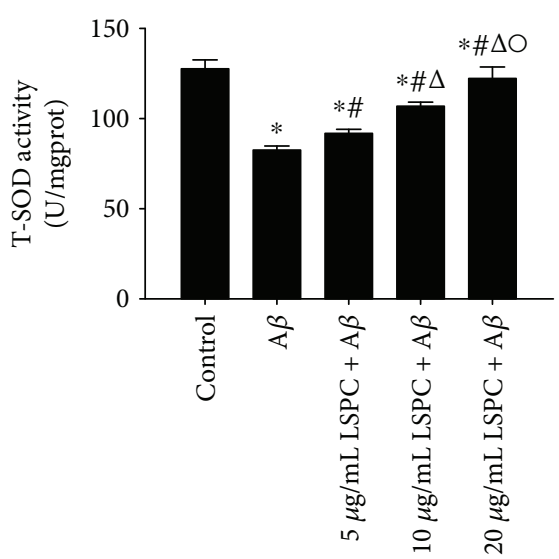

(b)

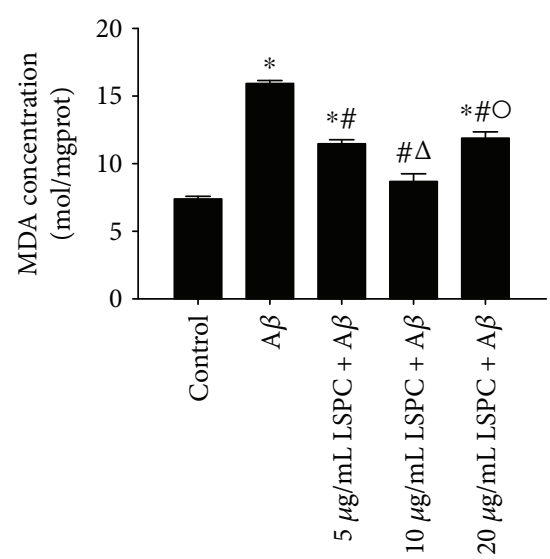

(c)

FIGURE 3: Oxidative index of different groups $(\overline{\mathrm{x}} \pm \mathrm{SEM}, n=6, \%)$. (a-c) The LDH concentration, T-SOD activity, and MDA concentration of different groups, respectively. Control, PC12 cells; A $\beta$, PC12 cells with $20 \mu \mathrm{M} \mathrm{A} \beta_{25-35} ; 5 \mu \mathrm{g} / \mathrm{mL} \mathrm{LSPC}+\mathrm{A} \beta$, PC12 cells added into $5 \mu \mathrm{g} / \mathrm{mL}$ LSPC 30 minutes before incubation with $20 \mu \mathrm{M} \mathrm{A} \beta_{25-35} ; 10 \mu \mathrm{g} / \mathrm{mL}$ LSPC $+\mathrm{A} \beta$, PC12 cells added into $10 \mu \mathrm{g} / \mathrm{mL}$ LSPC $30 \mathrm{minutes}$ before incubation with $20 \mu \mathrm{M} \mathrm{A} \beta_{25-35} ; 20 \mu \mathrm{g} / \mathrm{mL}$ LSPC $+\mathrm{A} \beta$, PC12 cells added into $20 \mu \mathrm{g} / \mathrm{mL}$ LSPC 30 minutes before incubation with $20 \mu \mathrm{M}$ $\mathrm{A} \beta_{25-35}$. All data are mean $\pm \mathrm{SEM}$. ${ }^{*} P<0.05$ for groups vs control; ${ }^{\#} P<0.05$ for groups vs $\mathrm{A} \beta$ group; ${ }^{\triangle} P<0.05$ for groups vs $5 \mu \mathrm{g} / \mathrm{mL}$ LSPC $+20 \mu \mathrm{M} \mathrm{A} \beta_{25-35}{ }^{\circ}{ }^{\circ} P<0.05$ for groups vs $10 \mu \mathrm{g} / \mathrm{mL} \mathrm{LSPC}+20 \mu \mathrm{M} \mathrm{A} \beta_{25-35}$. All the results above are the representative of the three independent experiments.

and fasted for $12 \mathrm{~h}$ but had access to deionized water. For the control group, physiological saline was given by oral gavage daily; for LSPC group, LSPC (a brownish red power) was dissolved in physiological saline $(20 \mathrm{mg} / \mathrm{mL})$ and administered to rats at a dose of $200 \mathrm{mg} / \mathrm{kg}$ body weight by oral gavage daily for two weeks. Body weights were measured every two days. Rats were sacrificed two hours later after a final dose. Tissues (brain, cardiac, liver, kidney, spleen, and pancreas), intestine content, and plasma were harvested and stored at $-80^{\circ} \mathrm{C}$ until analysis.

2.11. LC-MS/MS. For the extraction of LSPC and its metabolites, tissues $(60 \mathrm{mg})$ were homogenized with $300 \mu \mathrm{L}$ mixture $(50 \mu \mathrm{L} 1 \%(w / v)$ aqueous ascorbic solution and $250 \mu \mathrm{L}$ $0.1 \%$ formic acid). Ethyl gallate was an internal standard. Each sample was hydrolyzed with a $\beta$-glucuronidase/sulfatase type H1 $(1500 \mathrm{U} / \mathrm{mL})$ from H. pomatia (Sigma, USA) for two hours at $37^{\circ} \mathrm{C}$. Then, methanol $(200 \mu \mathrm{L})$ was added to each sample followed by vibration (30s) and centrifugation $\left(12000 \mathrm{rpm}, 10 \mathrm{~min}, 4^{\circ} \mathrm{C}\right.$ ), and the supernatant was collected. The extraction was repeated once. The combined supernatants were evaporated to dryness under vacuum at $35^{\circ} \mathrm{C}$. The residue was reconstituted in $50 \mu \mathrm{L}$ of solvent (methanol/water, $1: 1, v / v$ ) for LC-MS/MS analysis.

The analysis was performed on a high-performance liquid chromatography-tandem mass spectroscopy (LC-MS/ MS, AB Sciex QTrap 4500, Applied Biosystems, Foster City, CA, USA). This method was in accordance with the reported studies [30-32]. Briefly, $5 \mu \mathrm{L}$ samples were injected for LC-MS/MS, and the analytes were separated by BETASIL Phenyl Column $(2.1 \mathrm{~mm} \times 150 \mathrm{~mm}, 3 \mu \mathrm{m}$; Thermo Scientific, USA) at $35^{\circ} \mathrm{C}$. The mobile phases composed (a) water with $0.2 \%$ acetic acid and (b) methanol with $0.2 \%$ acetic acid. Ionization was carried out by electrospray in the negative mode. The calibration curves of respective standards were utilized to quantify compounds. Transition ions, retention times, and mass-spectrometry parameters for all compounds were shown in Table S1; chemical structures of all compounds were exhibited in Figure S1.

2.12. Statistical Analysis. The data are presented as mean values \pm standard error of the mean (SEM) and analyzed by ANOVA with Student-Newman-Keuls (SNK) or student $t$-test on SPSS software version 19.0. The level of significance was set for $P$ value $<0.05$.

\section{Results}

3.1. Dosages of $A \beta_{25-35}$ and LSPC. Figure 1(a) demonstrated that $20 \mu \mathrm{M} \mathrm{A} \beta_{25-35}$ had a significant effect on the survival rate of PC12 cells after $24 \mathrm{~h}$ intervention that was consistent with the previous report [33]. Thus, we chose the dosage of $20 \mu \mathrm{M} \mathrm{A} \beta_{25-35}$ with the intervention period of $24 \mathrm{~h}$ on PC12 cells for further study. In order to testify a dosedependent manner of LSPC, we added 1, 2.5, 5, 10, 20, and $40 \mu \mathrm{g} / \mathrm{mL}$ LSPC into PC1 2 cells before $\mathrm{A} \beta_{25-35}$ intervention, respectively. As shown in Figure 1(b), the survival rates of PC12 cells under the damage of $20 \mu \mathrm{M} \mathrm{A} \beta_{25-35}$ were gradually improved following the increasing dosages of LSPC until it reached $10 \mu \mathrm{g} / \mathrm{mL}$. Moreover, there was no toxicity in vitro for any dosage of LSPC. $10 \mu \mathrm{g} / \mathrm{mL}$ LSPC was chosen for further study since it exhibited the strongest protection on PC12 cells against the damage harvested from $20 \mu \mathrm{M} \mathrm{A} \beta_{25-35}$.

3.2. LSPC Inhibit $A \beta_{25-35}$-Induced Morphology Changes and Apoptosis on PC12 Cells. Cells were cultured in three groups: control group, PC12 cells with $20 \mu \mathrm{M} \mathrm{A} \beta_{25-35}$, and PC12 cells were added $10 \mu \mathrm{g} / \mathrm{mL}$ LSPC 30 minutes before incubation with $20 \mu \mathrm{M} \mathrm{A} \beta_{25-35}$. In electron microscope (Figures 2(a)-2(f)), PC12 cells with $10 \mu \mathrm{g} / \mathrm{mL}$ LSPC and $20 \mu \mathrm{M} \mathrm{A} \beta_{25-35}$ showed the approximate number of cells and identical cellular morphology as control group, 


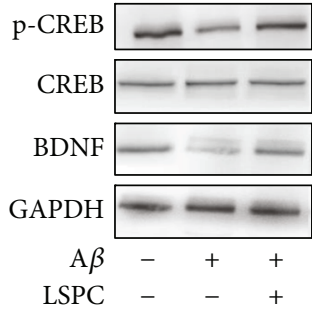

(a)

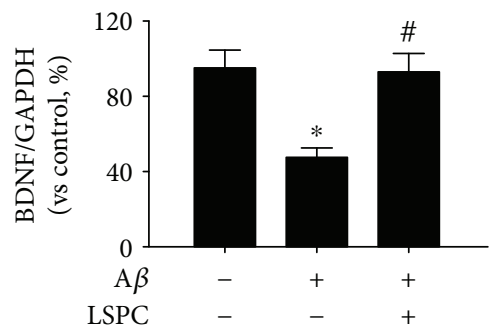

(c)

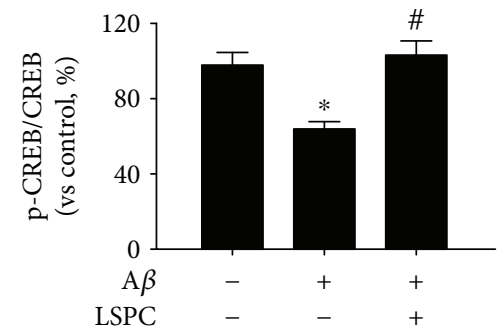

(b)

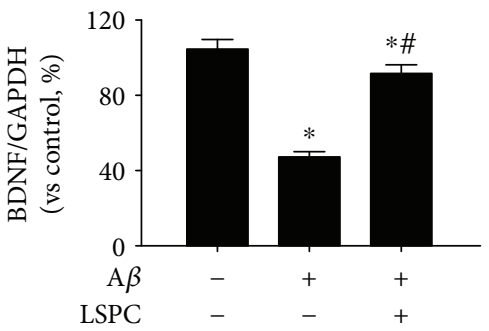

(d)

FIGURE 4: CREB/BDNF proteins expressions and mRNA expressions of intracellular BDNF in three groups (\% of control, $n=4)$. (a) CREB/ BDNF proteins expressions by Western blotting; (b) p-CREB/CREB proteins expressions by Western blotting in (a) (each group vs control, \%); (c) BDNF protein expressions by Western blotting in (a) (each group vs control, \%). Control, PC cells; A $\beta, \mathrm{PC} 12$ cells with $20 \mu \mathrm{M}$ A $\beta_{25-35}$ group; LSPC, PC1 2 cells with $10 \mu \mathrm{g} / \mathrm{mL}$ LSPC and $20 \mu \mathrm{M}$ A $\beta_{25-35}$ group. All data are mean \pm SEM. ${ }^{*} P<0.05$ for groups vs control group; ${ }^{\#} P<0.05$ for groups vs $\mathrm{A} \beta$ groups. (d) mRNA expression of intracellular BDNF in each group by qRT-PCR analysis. Cells were cultured as three groups as above, including control, $\mathrm{A} \beta$, and LSPC. All data are mean \pm SEM. ${ }^{*} P<0.05$ for groups vs control groups; ${ }^{\#} P<0.05$ for groups vs A $\beta$ groups. All the results above are the representative of the three independent experiments.

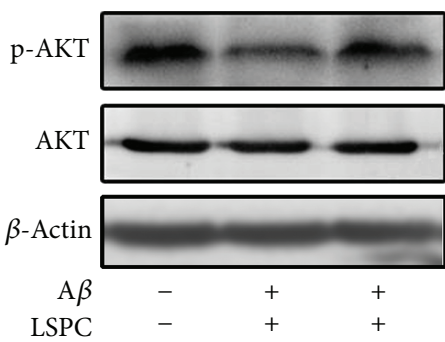

(a)

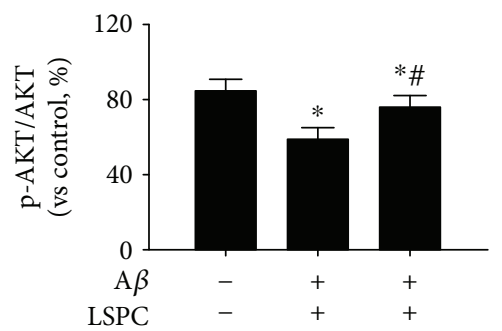

(c)

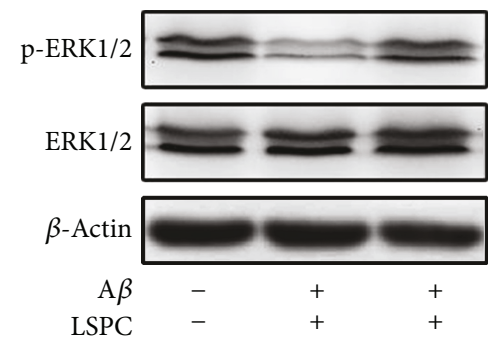

(b)

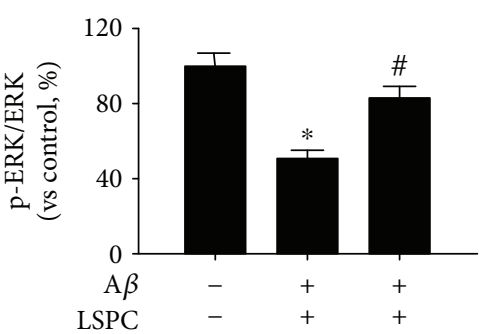

(d)

FIGURE 5: p-AKT/AKT and p-ERK/ERK proteins in each group (\% of control, $n=4)$. (a) p-AKT/AKT proteins expressions by Western blotting; (b) p-ERK/ERK proteins expressions by Western blotting; (c) p-AKT/AKT proteins expressions by western blotting in (a) (each group vs control, \%); (d) p-ERK/ERK proteins expressions by Western blotting in (b) (each group vs control, \%). Control, PC cells; A $\beta$, PC12 cells with $20 \mu \mathrm{M} \mathrm{A} \beta_{25-35}$ group; LSPC, PC12 cells with $10 \mu \mathrm{g} / \mathrm{mL}$ LSPC and $20 \mu \mathrm{M} \mathrm{A} \beta_{25-35}$ group. All data are mean \pm SEM. ${ }^{*} P<0.05$ for groups vs control groups; ${ }^{\#} P<0.05$ for groups vs $\mathrm{A} \beta$ groups. All the results above are the representative of the three independent experiments.

while PC12 cells with $20 \mu \mathrm{M} \mathrm{A} \beta_{25-35}$ exhibited decreased cells number as well as abnormal morphology that PC12 cells shortened and shrank. As Hoechst staining (Figure 2(g)) demonstrated, PC12 cells in $20 \mu \mathrm{M} \mathrm{A} \beta_{25-35}$ group suggested conspicuous karyopyknosis and cell apoptosis compared to control group while addition of $10 \mu \mathrm{g} / \mathrm{mL}$ LSPC prevented 


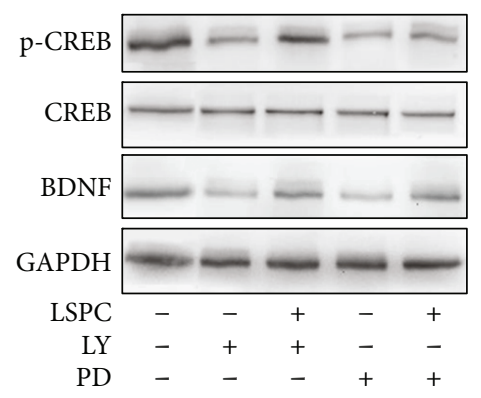

(a)

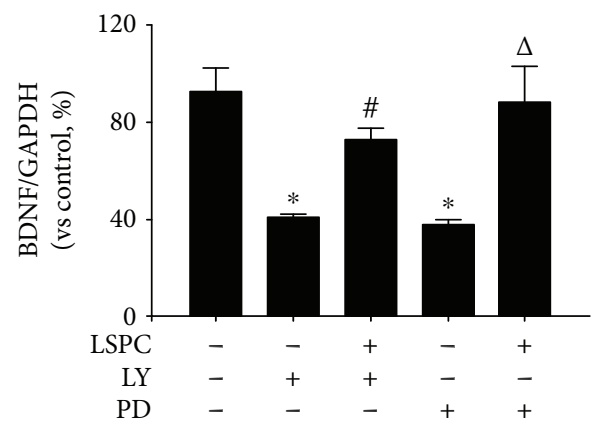

(c)

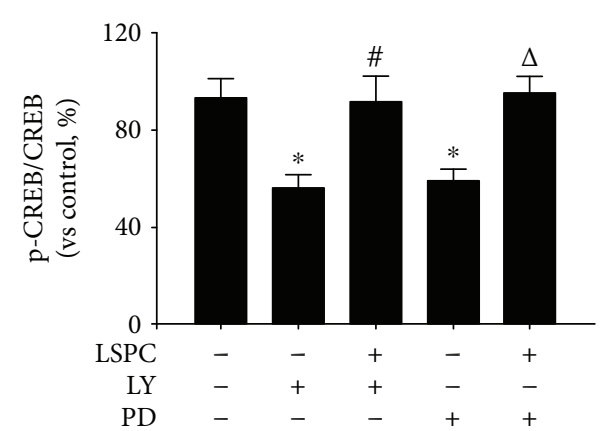

(b)

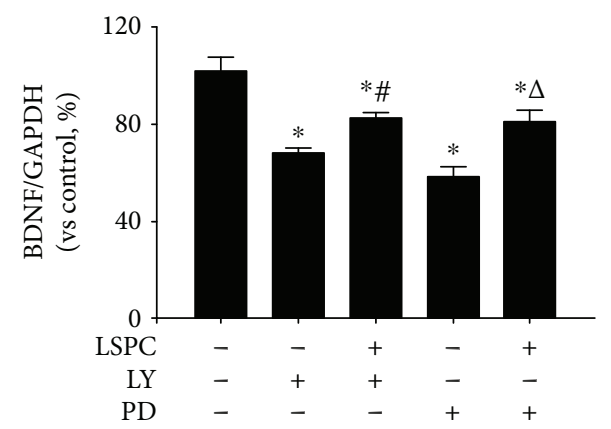

(d)

FIGURE 6: CREB/BDNF proteins expressions and mRNA expression of intracellular BDNF in five groups (\% of control, $n=4$ ). (a) CREB/ BDNF proteins expressions by Western blotting; (b) p-CREB/CREB proteins expressions by Western blotting in (a) (each group vs control, \%); (c) BDNF protein expressions by Western blotting in (a) (each group vs control, \%). Control, PC cells; LY, PC12 cells with $10 \mu \mathrm{M}$ LY294002; LSPC + LY, PC12 cells with $10 \mu \mathrm{g} / \mathrm{mL}$ LSPC and $10 \mu \mathrm{M}$ LY294002; PD, PC12 cells with $30 \mu \mathrm{M}$ PD98059; LSPC+PD, PC12 cells with $10 \mu \mathrm{g} / \mathrm{mL}$ LSPC and $30 \mu \mathrm{M}$ PD98059. All data are mean \pm SEM. ${ }^{*} P<0.05$ for groups vs control groups; ${ }^{\#} P<0.05$ for groups vs LY groups; ${ }^{\triangle} P<0.05$ for groups vs PD groups. (d) mRNA expression of intracellular BDNF in each group by qRT-PCR analysis. Cells were cultured as five groups as above, including control, LY, LSPC + LY, PD, and LSP + PD. All data are mean \pm SEM. ${ }^{*} P<0.05$ for groups vs control group; ${ }^{\#} P<0.05$ for groups vs LY groups; ${ }^{\triangle} P<0.05$ for groups vs $P D$ groups. All the results above are the representative of the three independent experiments.

the damage from $A \beta_{25-35}$ remarkably. In flow cytometry analysis (Figures $2(\mathrm{~h})$ and $2(\mathrm{i})$ ), we further validated that the apoptosis rates of PC12 cells with $20 \mu \mathrm{M} \mathrm{A} \beta_{25-35}$, including early apoptosis rates (AE), later apoptosis rates (LA), and total apoptosis rates (TA), were higher than that in the control $(P<0.05)$, and addition of $10 \mu \mathrm{g} / \mathrm{mL}$ LSPC significantly lessened apoptosis rates augmented by $\mathrm{A} \beta_{25-35}(P<0.05)$.

3.3. LSPC Protect PC12 Cells from $A \beta_{25-35}$-Induced Oxidative Stress. The antioxidant activity of LSPC against the $\mathrm{A} \beta_{25-35}$-induced damage on PC12 cells was determined by evaluating levels of LDH, MDA, and T-SOD. As shown in Figures 3(a)-3(c), compared to control group, PC12 cells with $20 \mu \mathrm{M} \mathrm{A} \beta_{25-35}$ had higher levels of intracellular MDA $(P<0.05)$ and extracellular LDH $(P<0.05)$ and a lower enzyme activity of T-SOD $(P<0.05) .5,10$, and $20 \mu \mathrm{g} / \mathrm{mL}$ LSPC all exhibited antioxidant activity. $10 \mu \mathrm{g} / \mathrm{mL}$ LSPC significantly reduced the levels of MDA and LDH among all groups and improved the activity of T-SOD on PC12 cells.

3.4. LSPC Ameliorate $A \beta_{25-35}$-Induced Downregulation of $C R E B / B D N F$ Signaling in PC12 Cells. To substantiate the alleviation effect by LSPC on $\mathrm{A} \beta_{25-35}$-induced damage via CREB/BDNF signaling, we employed three groups: control group, PC12 cells with $20 \mu \mathrm{M} \mathrm{A} \beta_{25-35}$ (A $\beta$ group), and PC12 cells with $20 \mu \mathrm{M} \mathrm{A} \beta_{25-35}$ after incubation with $10 \mu \mathrm{g} / \mathrm{mL}$ LSPC for 30 minutes (LSPC group). There was a significant discrepancy in $\mathrm{p}-\mathrm{CREB} / \mathrm{CREB}$ and $\mathrm{BDNF}$ expressions between the control group and $\mathrm{A} \beta$ group $(P<0.05)$ (Figure 4). LSPC promoted phosphorylation of CREB (Figures 4(a) and 4(b)) and augmented BDNF expression (Figures 4(a) and 4(c)), indicating that LSPC could mitigate $\mathrm{A} \beta_{25-35}$-induced diminishment of CREB phosphorylation and BDNF expression. qRT-PCR analysis of BDNF mRNA (Figure 4(d)) demonstrated that $\mathrm{A} \beta_{25-35}$ significantly attenuated BDNF mRNA expression compared with control group $(P<0.05)$ while LSPC counteracted the effect of $\mathrm{A} \beta_{25-35}$ on BDNF mRNA expression.

Upstream signaling of CREB/BDNF including PI3K/ AKT and Raf/ERK1/2 were analyzed through Western blotting (Figure 5). Both AKT and ERK phosphorylation were diminished after $\mathrm{A} \beta_{25-35}$ treatment. LSPC could conspicuously reverse the effects induced by $\mathrm{A} \beta(P<0.05)$.

To further identify CREB/BDNF signaling in neuroprotection of LSPC, we applied LY294002, an inhibitor of the PI3K/AKT pathway, and PD98059, an inhibitor of the ERK pathway. Cells were cultured as five groups: PC12 cells, PC12 cells with $10 \mu \mathrm{M}$ LY294002, PC12 cells with $10 \mu \mathrm{g} / \mathrm{mL}$ 


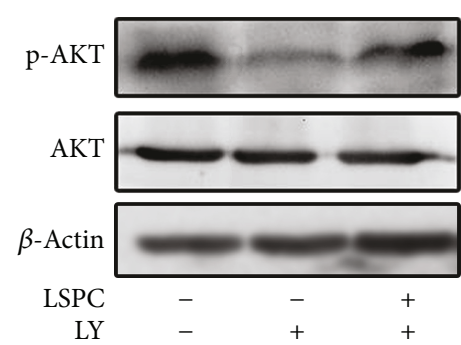

(a)

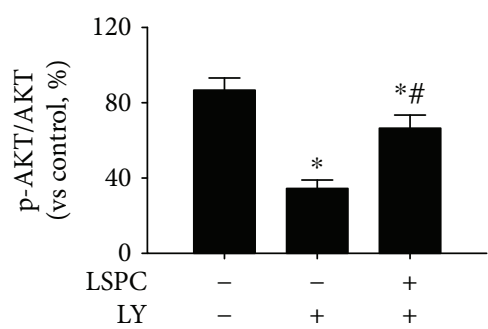

(c)

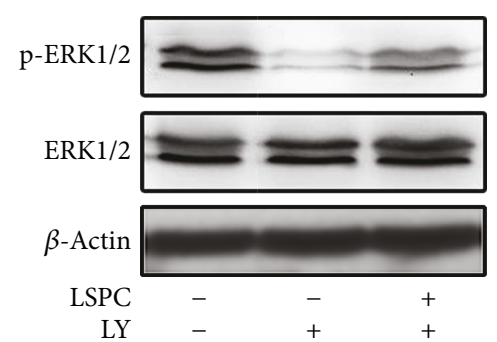

(b)

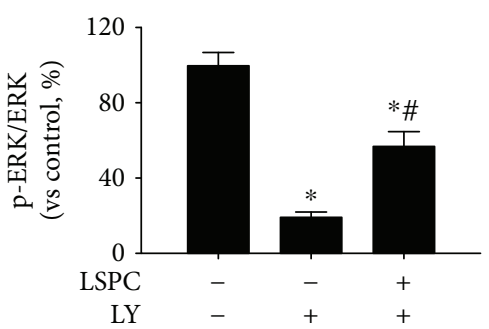

(d)

Figure 7: p-AKT/AKT and p-ERK/ERK proteins in each group (\% of control, $n=4)$. (a) p-AKT/AKT proteins expressions by Western blotting; (b) p-ERK/ERK proteins expressions by Western blotting; (c) p-AKT/AKT proteins expressions by Western blotting in (a) (each group vs control, \%); (d) p-ERK/ERK proteins expressions by western blotting in (b) (each group vs control, \%). Control, PC cells; LY, PC12 cells with $10 \mu \mathrm{M}$ LY294002; LSPC + LY, PC12 cells with $10 \mu \mathrm{g} / \mathrm{mL}$ LSPC and $10 \mu \mathrm{M}$ LY294002; PD, PC12 cells with $30 \mu \mathrm{M}$ PD98059; LSPC + PD, PC12 cells with $10 \mu \mathrm{g} / \mathrm{mL}$ LSPC and $30 \mu \mathrm{M}$ PD98059. All data are mean \pm SEM. ${ }^{*} P<0.05$ for groups vs control groups; ${ }^{\#} P<0.05$ for groups vs LY or PD groups. All the results above are the representative of the three independent experiments.

LSPC for 30 minutes before incubation with $10 \mu \mathrm{M}$ LY294002, PC12 cells with $30 \mu \mathrm{M}$ PD98059, PC12 cells with $10 \mu \mathrm{g} / \mathrm{mL}$ LSPC for 30 minutes before incubation with $30 \mu \mathrm{M}$ PD98059. In Figures 6(a)-6(c), LY294002 and PD98059 inhibited the expression of phosphorylation of CREB and BDNF while LSPC reversed the inhibition of LY294002 and PD98059 significantly $(P<0.05)$. In a qRT-PCR analysis of BDNF mRNA (Figure 6(d)), LY294002 and PD98059 notably lessened BDNF mRNA expression and LSPC enhanced BDNF mRNA expression in PC12 cells. Additionally, LSPC counteracted the reduction of AKT and ERK phosphorylation after LY294002 or PD98059 intervention (Figure 7).

3.5. Distribution of LSPC and Its Metabolites in Rat Tissues. As Tables 1(a) and 1(b), and 2 illustrated, after two weeks of consecutive LSPC administration, the quantities and formations of compounds varied in rat tissues and plasma. Summarily, PDB, epigallocatechin (EGC), and ECG were not detected in any rat tissues; syringic acid $(1.98 \pm 0.34)$ was slightly presented in plasma. After enzyme incubation, there were statistically significant differences $(P<0.05)$ about ferulic acid in pancreas and plasma, $\mathrm{m}$-coumaric acid in the brain tissue, pancreas, and plasma, and protocatechuic acid (PCC) in the brain tissue and plasma.

In brain (Table $1(\mathrm{a})$ and $1(\mathrm{~b})$ ), the quantities of quercetin, epicatechin, gallic acid, vanillic acid, m-coumaric acid, protocatechuic, 3-hydroxyphenylacetic acid (3-HPAA), and pyrocatechol significantly accrued in LSPC group. The enhancement of four compounds was verified after enzyme preprocess with LSPC intervention, these being quercetin, epicatechin, caffeic acid, and 3-HPAA, in both cardiac and liver. Besides, catechin accumulated in the cardiac tissues due to LSPC treatment; in the liver, homovanillic acid (HVA), gallic acid, and 3-hydroxybenzoic acid (3-HBA) increased markedly. Diverse compounds in the kidney (Table 1(a) and 1(b)) indicated significant differences between control and LSPC groups after enzyme disposal, including quercetin, catechin, epicatechin, HVA, caffeic acid, vanillic acid, 3,4-dihydroxyphenylacetic acid (3, 4-DHPA), 3-HBA, and pyrocatechol. In the pancreas (Table 1(a) and 1(b)), there was a remarkable increase in quercetin, ferulic acid, gallic acid, and m-coumaric acid, resulting from LSPC treatment. Apart from quercetin, 3, 4-DHPA alone in the spleen was confirmed to be significantly accrued after enzymolysis. LSPC administration contributed to the accumulations of quercetin, epicatechin, ferulic acid, HVA, caffeic acid, vanillic acid, 3-HBA, syringic acid, p-HPPA, $\mathrm{m}$-coumaric, PCC, and pyrocatechol in plasma (Table 2).

There was no significant difference in body weight between the control group and LSPC group after LSPC treatment (Figure S2). Catechin and epicatechin were distinguished by LC-MS/MS according to distinctive retention time and transition ions.

\section{Discussion}

Recently, there has been an increasing interest in the discovery of potential flavonoids for preventing dementia or $\mathrm{AD}$; nevertheless, the complexity and diversity of flavonoids restrict the understanding of their value on $\mathrm{AD}$ treatment. This study comprehensively verified its anti- $\mathrm{A} \beta$ neurotoxicity in vitro that could alleviate $\mathrm{AD}$-related symptoms.

In $\mathrm{AD}, \mathrm{A} \beta$ may contribute to oxidative stress in the brain $[1,34]$ while the antioxidant activity is an outstanding feature 
TABLE 1: Quantities of compounds in rat tissues of control and LSPC groups.

(a)

\begin{tabular}{|c|c|c|c|c|c|c|}
\hline \multirow[b]{2}{*}{ Compound (ng/g) } & \multicolumn{2}{|c|}{ Brain } & \multicolumn{2}{|c|}{ Cardiac } & \multicolumn{2}{|c|}{ Liver } \\
\hline & $\begin{array}{c}\text { Control } \\
\text { Mean } \pm \text { SEM }\end{array}$ & $\begin{array}{c}\text { LSPC } \\
\text { Mean } \pm \text { SEM }\end{array}$ & $\begin{array}{c}\text { Control } \\
\text { Mean } \pm \text { SEM }\end{array}$ & $\begin{array}{c}\text { LSPC } \\
\text { Mean } \pm \text { SEM }\end{array}$ & $\begin{array}{c}\text { Control } \\
\text { Mean } \pm \text { SEM }\end{array}$ & $\begin{array}{c}\text { LSPC } \\
\text { Mean } \pm \text { SEM }\end{array}$ \\
\hline PDB & ND & ND & ND & ND & ND & ND \\
\hline ECG & ND & ND & ND & ND & ND & ND \\
\hline EGC & ND & ND & ND & ND & ND & ND \\
\hline Quercetin & $35.84 \pm 2.63$ & $46.72 \pm 2.57^{*}$ & $29.29 \pm 1.54$ & $40.96 \pm 2.54^{* *}$ & $27.71 \pm 1.45$ & $49.12 \pm 3.63^{* * *}$ \\
\hline Catechin & ND & ND & ND & $7.96 \pm 3.47^{*}$ & ND & $7.59 \pm 6.59$ \\
\hline Epicatechin & ND & $82.36 \pm 7.79^{* * *}$ & ND & $66.36 \pm 31.51$ & ND & $55.50 \pm 9.13^{* * *}$ \\
\hline Syringic acid & ND & ND & ND & ND & ND & ND \\
\hline Ferulic acid & $54.21 \pm 3.81$ & $84.45 \pm 8.96$ & ND & ND & ND & ND \\
\hline HVA & $142.07 \pm 12.50$ & $236.36 \pm 63.98$ & ND & ND & $1.52 \pm 0.94$ & $19.36 \pm 2.53^{* * *}$ \\
\hline Caffeic acid & $109.07 \pm 3.95$ & $120.93 \pm 5.73$ & $86.50 \pm 1.70$ & $96.00 \pm 3.57^{*}$ & $79.50 \pm 1.70$ & $92.50 \pm 4.98^{*}$ \\
\hline Gallic acid & $39.88 \pm 2.83$ & $69.36 \pm 4.72^{* * *}$ & $12.44 \pm 1.44$ & $20.48 \pm 3.30$ & $17.74 \pm 3.15$ & $30.13 \pm 4.09^{*}$ \\
\hline Vanillic acid & $67.92 \pm 11.19$ & $122.50 \pm 17.15^{*}$ & ND & ND & ND & ND \\
\hline 3,4-DHPA & $154.21 \pm 22.81$ & $361.71 \pm 162.66$ & $18.64 \pm 1.92$ & $21.89 \pm 2.08$ & ND & ND \\
\hline p-HPPA & $14.29 \pm 2.75$ & $22.29 \pm 3.66$ & $22.31 \pm 13.30$ & $9.43 \pm 3.24$ & $8.99 \pm 6.41$ & $28.09 \pm 7.20$ \\
\hline $\mathrm{m}$-Coumaric acid & $9.26 \pm 0.98$ & $13.20 \pm 0.97^{*}$ & ND & ND & ND & ND \\
\hline PCC & $183.64 \pm 11.80$ & $231.29 \pm 16.06^{*}$ & $211.21 \pm 12.03$ & $279.43 \pm 40.98$ & $112.14 \pm 6.73$ & $152.93 \pm 19.14$ \\
\hline 3-HPAA & $16.03 \pm 1.16$ & $25.47 \pm 2.65^{* *}$ & $18.81 \pm 0.77$ & $26.89 \pm 3.00^{*}$ & $104.00 \pm 9.17$ & $170.86 \pm 13.76^{*}$ \\
\hline 3-HBA & $58.11 \pm 12.87$ & $83.49 \pm 38.02$ & $10.53 \pm 4.37$ & $8.26 \pm 1.81$ & ND & $4.13 \pm 0.73^{* *}$ \\
\hline Pyrocatechol & $94.21 \pm 5.88$ & $124.79 \pm 9.49^{*}$ & $54.54 \pm 2.66$ & $63.49 \pm 5.27$ & $13.46 \pm 1.94$ & $21.16 \pm 2.92$ \\
\hline
\end{tabular}

(b)

\begin{tabular}{|c|c|c|c|c|c|c|}
\hline \multirow[b]{2}{*}{ Compound (ng/g) } & \multicolumn{2}{|c|}{ Kidney } & \multicolumn{2}{|c|}{ Spleen } & \multicolumn{2}{|c|}{ Pancreas } \\
\hline & $\begin{array}{c}\text { Control } \\
\text { Mean } \pm \text { SEM }\end{array}$ & $\begin{array}{c}\text { LSPC } \\
\text { Mean } \pm \text { SEM }\end{array}$ & $\begin{array}{c}\text { Control } \\
\text { Mean } \pm \text { SEM }\end{array}$ & $\begin{array}{c}\text { LSPC } \\
\text { Mean } \pm \text { SEM }\end{array}$ & $\begin{array}{c}\text { Control } \\
\text { Mean } \pm \text { SEM }\end{array}$ & $\begin{array}{c}\text { LSPC } \\
\text { Mean } \pm \text { SEM }\end{array}$ \\
\hline PDB & ND & ND & $\mathrm{ND}$ & ND & ND & ND \\
\hline ECG & ND & ND & ND & ND & ND & ND \\
\hline EGC & ND & ND & ND & ND & ND & ND \\
\hline Quercetin & $20.40 \pm 1.27$ & $49.55 \pm 2.99^{* * *}$ & $29.13 \pm 1.56$ & $38.49 \pm 3.66^{*}$ & $17.55 \pm 6.23$ & $50.78 \pm 3.15^{* * *}$ \\
\hline Catechin & ND & $7.01 \pm 1.66^{* *}$ & ND & ND & ND & ND \\
\hline Epicatechin & ND & $32.40 \pm 4.37^{* * *}$ & ND & $33.71 \pm 21.76$ & ND & ND \\
\hline Syringic acid & ND & ND & ND & ND & ND & ND \\
\hline Ferulic acid & ND & ND & ND & ND & $18.49 \pm 7.86$ & $41.51 \pm 3.58^{*}$ \\
\hline HVA & $14.46 \pm 3.31$ & $73.71 \pm 9.05^{* * *}$ & ND & ND & ND & ND \\
\hline Caffeic acid & $71.00 \pm 2.25$ & $101.50 \pm 5.90^{* *}$ & $51.88 \pm 2.60$ & $52.31 \pm 2.93$ & $114.43 \pm 6.23$ & $126.86 \pm 7.82$ \\
\hline Gallic acid & $25.64 \pm 1.35$ & $51.12 \pm 17.29$ & $22.47 \pm 1.69$ & $26.72 \pm 1.16$ & $30.32 \pm 5.58$ & $47.08 \pm 1.43^{*}$ \\
\hline Vanillic acid & ND & $21.83 \pm 7.41^{*}$ & $\mathrm{ND}$ & ND & $23.72 \pm 6.33$ & $44.05 \pm 7.34$ \\
\hline 3,4-DHPA & $9.34 \pm 1.83$ & $20.89 \pm 2.45^{* *}$ & $9.19 \pm 2.48$ & $19.31 \pm 1.24^{* *}$ & ND & ND \\
\hline p-HPPA & $85.69 \pm 61.94$ & $279.71 \pm 67.66$ & $5.65 \pm 2.74$ & $12.77 \pm 3.75$ & ND & $\mathrm{ND}$ \\
\hline m-Coumaric acid & ND & $20.05 \pm 13.39$ & ND & ND & $17.88 \pm 3.71$ & $36.21 \pm 4.51^{* *}$ \\
\hline PCC & $118.43 \pm 10.88$ & $134.29 \pm 8.74$ & $145.71 \pm 16.17$ & $152.14 \pm 17.77$ & $216.86 \pm 17.69$ & $229.21 \pm 12.45$ \\
\hline 3-HPAA & $15.31 \pm 1.37$ & $21.62 \pm 3.21$ & $2.82 \pm 1.11$ & $2.14 \pm 0.73$ & $40.83 \pm 3.56$ & $49.78 \pm 4.52$ \\
\hline
\end{tabular}


TABle 1: Continued.

\begin{tabular}{lcccccc}
\hline \multirow{2}{*}{ Compound (ng/g) } & $\begin{array}{c}\text { Control } \\
\text { Mean } \pm \text { SEM }\end{array}$ & $\begin{array}{c}\text { LSPC } \\
\text { Mean } \pm \text { SEM }\end{array}$ & $\begin{array}{c}\text { Control } \\
\text { Mean } \pm \text { SEM }\end{array}$ & $\begin{array}{c}\text { Spleen } \\
\text { Mean } \pm \text { SEM }\end{array}$ & $\begin{array}{c}\text { Pancreas } \\
\text { Mean } \pm \text { SEM }\end{array}$ & $\begin{array}{c}\text { LSPC } \\
\text { Mean } \pm \text { SEM }\end{array}$ \\
\hline 3-HBA & $5.40 \pm 0.68$ & $26.16 \pm 2.60^{* * *}$ & $3.12 \pm 0.87$ & $4.29 \pm 0.99$ & ND & ND \\
Pyrocatechol & $19.98 \pm 1.67$ & $33.25 \pm 3.60^{* *}$ & $16.56 \pm 2.84$ & $16.81 \pm 3.78$ & $69.26 \pm 5.06$ & $70.64 \pm 3.89$ \\
\hline
\end{tabular}

Note: control and LSPC represent different intervention groups, respectively. PDB, ECG, EGC, HVA, 3,4-DHPA, p-HPPA, PCC, 3-HPAA, and 3-HBA stand for procyanidin dimer B, epicatechin gallate, epigallocatechin, homovanillic acid, 3,4-dihydroxyphenylacetic acid, 3-(4-hydroxyphenyl)propionic acid, protocatechuic acid, 3-hydroxyphenylacetic acid, and 3-hydroxybenzoic acid, respectively. Values represent the concentrations of metabolites in different rat tissues, and they were all presented as the means \pm SEM $(n=7)$; ND = not detected; ${ }^{*}{ }^{* *},{ }^{* * *}$ indicates significant differences between two groups with or without LSPC $(p<0.05, p<0.01$, and $p<0.001)$, respectively.

TABLE 2: Quantities of compounds in rat plasma of control and LSPC groups.

\begin{tabular}{|c|c|c|}
\hline \multirow[b]{2}{*}{ Compound (ng/mL) } & \multicolumn{2}{|c|}{ Plasma } \\
\hline & $\begin{array}{c}\text { Control } \\
\text { Mean } \pm \text { SEM }\end{array}$ & $\begin{array}{c}\text { LSPC } \\
\text { Mean } \pm \text { SEM }\end{array}$ \\
\hline $\mathrm{PDB}$ & ND & $\mathrm{ND}$ \\
\hline ECG & ND & ND \\
\hline EGC & ND & ND \\
\hline Quercetin & $5.83 \pm 0.31$ & $7.70 \pm 0.73^{*}$ \\
\hline Catechin & ND & ND \\
\hline Epicatechin & ND & $9.38 \pm 3.45^{*}$ \\
\hline Syringic acid & ND & $1.98 \pm 0.34^{* * *}$ \\
\hline Ferulic acid & $8.95 \pm 3.59$ & $31.77 \pm 4.24^{* *}$ \\
\hline HVA & $6.64 \pm 0.40$ & $29.59 \pm 3.63^{* * *}$ \\
\hline Caffeic acid & $10.36 \pm 1.48$ & $40.44 \pm 9.68^{* *}$ \\
\hline Gallic acid & ND & ND \\
\hline Vanillic acid & $39.97 \pm 2.52$ & $86.96 \pm 7.60^{* * *}$ \\
\hline 3,4-DHPA & ND & ND \\
\hline p-HРPA & $23.22 \pm 16.84$ & $122.97 \pm 10.64^{* * *}$ \\
\hline m-Coumaric acid & $7.86 \pm 5.63$ & $24.90 \pm 3.00^{*}$ \\
\hline PCC & $2.21 \pm 0.36$ & $10.95 \pm 2.55^{* *}$ \\
\hline 3-HPAA & $4.63 \pm 0.41$ & $6.77 \pm 0.94$ \\
\hline 3-HBA & $4.10 \pm 0.26$ & $13.86 \pm 0.90^{* * *}$ \\
\hline Pyrocatechol & $1.27 \pm 0.47$ & $4.73 \pm 0.68^{* *}$ \\
\hline
\end{tabular}

Note: control and LSPC represent different intervention groups, respectively. PDB, ECG, EGC, HVA, 3,4-DHPA, p-HPPA, PCC, 3-HPAA, and 3-HBA stand for procyanidin dimer B, epicatechin gallate, epigallocatechin, homovanillic acid, 3,4-dihydroxyphenylacetic acid, 3-(4hydroxyphenyl)propionic acid, protocatechuic acid, 3-hydroxyphenylacetic acid, and 3-hydroxybenzoic acid, respectively. Values represent the concentrations of metabolites in different rat tissues, and they were all presented as the means $\pm \operatorname{SEM}(n=7) ; \mathrm{ND}=$ not detected; ${ }^{*},{ }^{* *},{ }^{* * *}$ indicates significant differences between two groups with or without LSPC $(p<0.05, p<0.01$, and $p<0.001)$, respectively.

of flavonoids. PC12 cells with $\mathrm{A} \beta_{25-35}$, as an AD-like model, were performed to testify the abilities about anti-A $\beta$ neurotoxicity of LSPC $[35,36]$. LSPC has no toxicity in vitro and in vivo that coincided with previous studies [27, 37]. LSPC has exhibited its antioxidation effect in vitro that was consistent with $\mathrm{Xu}$ et al. [27]. Interestingly, a higher concentration of LSPC $(20 \mathrm{mg} / \mathrm{L})$ seemed to be less efficient in the decrease of MDA and $\mathrm{LDH}$, and a dose-response could be seen regarding the SOD activity. This result could be partly due to the difference in antioxidant activity associated with doses of procyanidins, cell type, and time of exposure [38]. The inconsistency of different antioxidant enzymes activities has been reported by Puiggròs et al. [39]. Antioxidant reactions of flavonoids, as illustrated by many studies, may benefit the treatment and precaution of cancer [40], cardiovascular diseases [41, 42], type 2 diabetes [41, 42], and neurodegenerative diseases [43]. Since periphery anti-A $\beta$ has been proposed as potential approaches to ameliorate impairment of $\mathrm{A} \beta[44,45]$ in the central nervous system that the liver and kidney have been tightly related to it $[44,46]$, it is a high possibility that antioxidant effect of LSPC could contribute to alleviate $\mathrm{A} \beta$ toxicity in this pathway.

Not only oxidative stress is attributed to accumulation and neurotoxicity of $\mathrm{A} \beta$ in $\mathrm{AD}$ but also downregulation of CREB/BDNF signaling [5, 12-14]. Several studies have shed the light on anti-A $\beta$ effect of flavonoids [47-49]. Lin et al. have reported that $\mathrm{A} \beta$ could induce the death of cells [50], and in $\mathrm{AD}$, it is a major damage resulted from $\mathrm{A} \beta$ aggregation [51]. According to Hoechst staining and flow cytometry in the present study, LSPC kept cellular morphology from deformation and suppressed the apoptosis of cells induced by $A \beta$. In addition, $A \beta$ can reduce the expression of BDNF in $\mathrm{AD}$ [52], and CREB can mediate $\mathrm{A} \beta$-induced BDNF downregulation [53] that are in accordance with our results. CREB/BDNF signaling was downregulated by $\mathrm{A} \beta$ but upregulated by LSPC. Through targeting phosphorylation of CREB, AKT, and ERK, the upstream of CREB/BDNF signaling can affect BDNF transcription $[6,7]$. Activations of both AKT and ERK were restrained by $A \beta[8,9]$ but increased with treatment of LSPC in our study. CREB/BDNF signaling plays a vital role in neuron survival, and BDNF-based synaptic repair is proposed as a therapeutic strategy for $\mathrm{AD}$ [54]. LSPC could hence ameliorate $A \beta$-induced damage in $A D$ through CREB/BDNF signaling. Notably, an interaction between CREB/BDNF signaling and oxidative stress has been confirmed $[18,19]$. Valvassori et al. have reported that increased BDNF in the brain can modulate oxidative stress [55]. Taken together, LSPC has both antioxidative effects and the ability to regulate $\mathrm{CREB} / \mathrm{BDNF}$ signaling as a potential $\mathrm{AD}$ pretreatment. Several researches focusing on lotus also support that compounds from lotus may show neuroprotection [20]. 


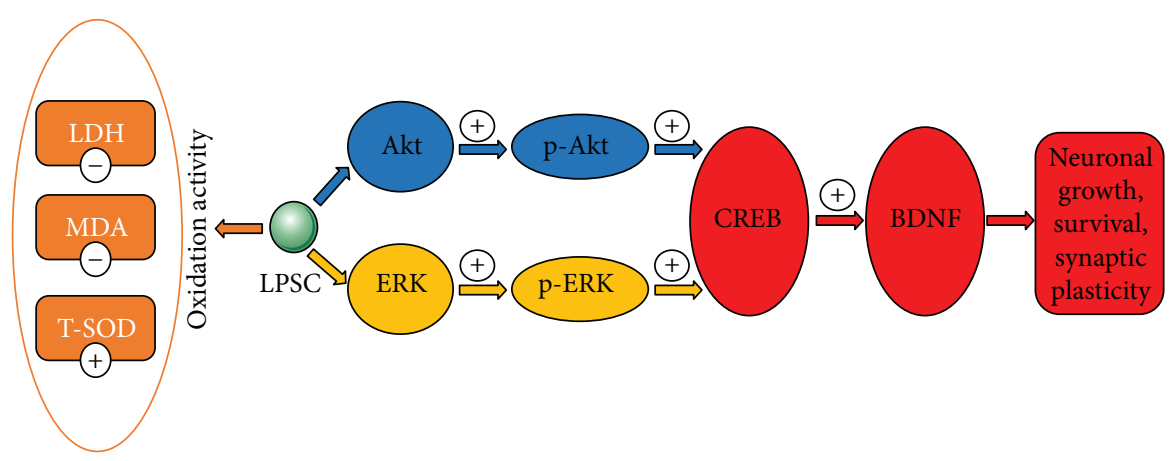

FIGURE 8: Schematic diagram shows anti-A $\beta$ effects of LSPC on PC12 cells. CREB/BDNF signaling plays a significant role in neuronal growth, survival, and synaptic plasticity. $\mathrm{A} \beta$ can increase the apoptosis rates of cells and deform the cellular morphology since $\mathrm{A} \beta$ may lead to downregulation of CREB phosphorylation and BDNF expression. LSPC can reverse the effect of $\mathrm{A} \beta$ that it can improve the survival rates of cells and maintain the cellular morphology. LSPC may promote the upstream signaling of CREB/BDNF, including AKT and ERK phosphorylation, which can enhance CREB phosphorylation and BDNF expression. Additionally, A $\beta$ may contribute to higher levels of MDA and LDH and the lower activity of T-SOD. LSPC can mitigate A $\beta$-induced damage through reducing the level of MDA and LDH and improving the activity of T-SOD. LSPC, procyanidins extracted from the lotus seedpod; A $\beta$, amyloid- $\beta$; PC12, rat pheochromocytoma cells; BDNF, brain-derived neurotrophic factor; CREB, cAMP-responsive element-binding; LDH, lactate dehydrogenase; SOD, superoxide dismutase; MDA, malonialdehyde.

By LC-MS/MS, we found several detectable compositions accumulated in vivo and quantities of them were varied in rat tissues and plasma after consecutive LSPC administration. As reported, $\mathrm{A} \beta$ can aggravate in both central and periphery tissues and the relationship between $\mathrm{AD}$ and the peripheral system is indivisible $[56,57]$. AD has been called as "type 3 diabetes", concerning its association with insulin resistance [58]; it also has been related to the gut-brain axis [59]. The distribution of LSPC was only measured in rat urine before so it was profound to confirm the distribution of it in vivo. In the LSPC group, epicatechin and quercetin, resulted from quercetin-3-O-glucuronide in LSPC [25], were found to accumulate in the brain. Wang et al. [16] have reported 3'-Omethyl-epicatechin-5-O- $\beta$-glucuronide, the major metabolites of epicatechin in the brain, may promote long-term potentiation (LTP) through CREB signaling. Quercetin-3-Oglucuronide has been reported to cross the blood-brain barrier and accumulate in the brain [60,61]; deconjugation of it may contribute to the appearance of quercetin in tissues [61]. Quercetin-3-O-glucuronide has also been identified to inhibit $\mathrm{A} \beta$ aggregation [60] and reduce oxidative stress [61, 62]. The increment of BDNF protein and AKT phosphorylation in the rat by quercetin-3-O-glucuronide has been observed by Baral et al. [63]. Serra et al. [64] have discussed the distribution of procyanidins from hazelnut extract after treatment once, reporting only p-HPPA is significantly increased in the brain. Conversely, our results showed that LSPC could lead to the accumulation of quercetin, epicatechin, gallic acid, vanillic acid, m-coumaric acid, protocatechuic, 3-HPAA, and pyrocatechol. This inconsistency could be ascribed to the difference between LSPC and hazelnut extract and intervention time.

Other compounds in the brain detected to increase in LSPC group, including gallic acid [65], vanillic acid [66], and protocatechuic acid [67], have been discussed to anti$\mathrm{A} \beta$ neurotoxicity through multifarious pathways. Gallic acid could inhibit $\mathrm{A} \beta$ neurotoxicity through suppressing

neuroinflammation [65]; vanillic acid is found to attenuate oxidative stress induced by $A \beta$ [66]; protocatechuic acid may also minimize inflammatory response [67]. But evidences about these materials are insufficient. Further studies are required to discern and compare the effects of different compounds after LSPC treatment as an integral or as separated components.

\section{Conclusion}

Our research firstly affirmed anti-A $\beta$ effectiveness of LSPC that indicated it as a promising pretreatment for $\mathrm{AD}$ and expounded LSPC distribution in vivo. Through cell experiments, our study not only proved anti-A $\beta$ effects of LSPC through evaluation of cell viability and cellular morphology but also identified the antioxidant effect of LSPC and $\mathrm{BDNF} / \mathrm{CREB}$ signaling in its anti-A $\beta$ mechanisms (Figure 8). We also applied LC-MS/MS in the detection of LSPC in vivo that contributed to explain its effect. Future studies still need to enrich our scientific recognition of LSPC and then establish the novel therapeutic strategies for $\mathrm{AD}$.

\section{Abbreviations}

$\mathrm{AD}$ :

LSPC:

$\mathrm{A} \beta$ :

LC-MS/MS:

PC12:

BDNF:

CREB:

AKT:

ERK:

CCK-8:
Alzheimer's disease

Procyanidins extracted from the lotus seedpod

Amyloid- $\beta$

High-performance liquid chromatography-tandem mass spectroscopy

Rat pheochromocytoma cells Brain-derived neurotrophic factor cAMP-responsive element-binding Protein kinase B Extracellular signal-regulated kinase Cell counting Kit-8 


$\begin{array}{ll}\text { LDH: } & \text { Lactate dehydrogenase } \\ \text { SOD: } & \text { Superoxide dismutase } \\ \text { MDA: } & \text { Malonialdehyde } \\ \text { RPMI: } & \text { Roswell Park Memorial Institute } \\ \text { PI: } & \text { Propidium iodide } \\ \text { EA: } & \text { Early apoptosis } \\ \text { LA: } & \text { Late apoptosis } \\ \text { TA: } & \text { Total apoptosis } \\ \text { PVDF: } & \text { Polyvinylidene difluoride } \\ \text { qRT-PCR: } & \text { Quantitative reverse transcription PCR } \\ \text { SEM: } & \text { Standard error of mean } \\ \text { SNK: } & \text { Student-Newman-Keuls } \\ \text { PDB, ECG, EGC, } & \text { Procyanidin dimer B, epicatechin gallate, } \\ \text { HVA, 3,4-DHPA, epigallocatechin, homovanillic acid, 3,4- } \\ \text { p-HPPA, PCC, } & \text { dihydroxyphenylacetic acid, 3-(4-hydro- } \\ \text { 3-HPAA, and } & \text { xyphenyl)propionic acid, protocatechuic } \\ \text { 3-HBA: } & \text { acid, 3-hydroxyphenylacetic acid, and } \\ & \text { 3-hydroxybenzoic acid, respectively } \\ \text { LTP: } & \text { Long-term potentiation. }\end{array}$

\section{Data Availability}

The data is available on the website of Figshare and the access is https://figshare.com/s/fb5f71daf2ef08cdff42.

\section{Conflicts of Interest}

The authors declare that there is no conflict of interest regarding the publication of this paper.

\section{Acknowledgments}

We are thankful for the help from Professor Keqiang Ye (Department of Pathology and Laboratory Medicine, Emory University School of Medicine, Atlanta, USA). This study was supported by the National Natural Science Foundation of China (81472978).

\section{Supplementary Materials}

Figure S1: chemical structures of all analytes. Figure S2: body weights of rats fed as control group and LSPC group. Table S1: formula, transition ions, retention times, and mass spectrometry parameters for all compounds. (Supplementary Materials)

\section{References}

[1] Y. Huang and L. Mucke, "Alzheimer mechanisms and therapeutic strategies,” Cell, vol. 148, no. 6, pp. 1204-1222, 2012.

[2] J. A. Hardy and G. A. Higgins, "Alzheimer's disease: the amyloid cascade hypothesis,” Science, vol. 256, no. 5054, pp. 184185, 1992.

[3] J. Hardy and D. J. Selkoe, "The amyloid hypothesis of Alzheimer's disease: progress and problems on the road to therapeutics," Science, vol. 297, no. 5580, pp. 353-356, 2002.

[4] C. Ising, M. Stanley, and D. M. Holtzman, "Current thinking on the mechanistic basis of Alzheimer's and implications for drug development," Clinical Pharmacology \& Therapeutics, vol. 98, no. 5, pp. 469-471, 2015.
[5] M. P. Mattson, "Pathways towards and away from Alzheimer's disease," Nature, vol. 430, no. 7000, pp. 631-639, 2004.

[6] B. Bozon, A. Kelly, S. A. Josselyn, A. J. Silva, S. Davis, and S. Laroche, "MAPK, CREB and zif268 are all required for the consolidation of recognition memory," Philosophical Transactions of the Royal Society of London. Series B, Biological Sciences, vol. 358, no. 1432, pp. 805-814, 2003.

[7] W. Wang, Y. Lu, Z. Xue et al., "Rapid-acting antidepressantlike effects of acetyl-1-carnitine mediated by PI3K/AKT/ BDNF/VGF signaling pathway in mice," Neuroscience, vol. 285, pp. 281-291, 2015.

[8] S. Jimenez, M. Torres, M. Vizuete et al., "Age-dependent accumulation of soluble amyloid beta (Abeta) oligomers reverses the neuroprotective effect of soluble amyloid precursor protein- $\alpha(\operatorname{sAPP} \alpha)$ by modulating phosphatidylinositol 3-kinase (PI3K)/Akt-GSK-3beta pathway in Alzheimer mouse model," The Journal of Biological Chemistry, vol. 286, no. 21, pp. 18414-18425, 2011.

[9] C. Lu, Y. Wang, D. Wang et al., "Neuroprotective effects of soy isoflavones on scopolamine-induced amnesia in mice," Nutrients, vol. 10, no. 7, 2018.

[10] C. R. Bramham and E. Messaoudi, "BDNF function in adult synaptic plasticity: the synaptic consolidation hypothesis," Progress in Neurobiology, vol. 76, no. 2, pp. 99-125, 2005.

[11] C. G. Causing, A. Gloster, R. Aloyz et al., "Synaptic innervation density is regulated by neuron-derived BDNF," Neuron, vol. 18 , no. 2, pp. 257-267, 1997.

[12] M. Fahnestock, "Brain-derived neurotrophic factor: the link between amyloid- $\beta$ and memory loss," Future Neurology, vol. 6, no. 5, pp. 627-639, 2011.

[13] D. J. Garzon and M. Fahnestock, "Oligomeric amyloid decreases basal levels of brain-derived neurotrophic factor (BDNF) mRNA via specific downregulation of BDNF transcripts IV and V in differentiated human neuroblastoma cells," The Journal of Neuroscience, vol. 27, no. 10, pp. 2628-2635, 2007.

[14] S. Peng, D. J. Garzon, M. Marchese et al., "Decreased brainderived neurotrophic factor depends on amyloid aggregation state in transgenic mouse models of Alzheimer's disease," The Journal of Neuroscience, vol. 29, no. 29, pp. 9321-9329, 2009.

[15] C. M. Williams, M. A. el Mohsen, D. Vauzour et al., "Blueberry-induced changes in spatial working memory correlate with changes in hippocampal CREB phosphorylation and brain-derived neurotrophic factor (BDNF) levels," Free Radical Biology \& Medicine, vol. 45, no. 3, pp. 295-305, 2008.

[16] J. Wang, M. G. Ferruzzi, L. Ho et al., "Brain-targeted proanthocyanidin metabolites for Alzheimer's disease treatment," The Journal of Neuroscience, vol. 32, no. 15, pp. 51445150, 2012.

[17] S. M. Massa, T. Yang, Y. Xie et al., "Small molecule BDNF mimetics activate TrkB signaling and prevent neuronal degeneration in rodents," The Journal of Clinical Investigation, vol. 120, no. 5, pp. 1774-1785, 2010.

[18] A. Wu, Z. Ying, and F. Gomez-Pinilla, "The interplay between oxidative stress and brain-derived neurotrophic factor modulates the outcome of a saturated fat diet on synaptic plasticity and cognition," The European Journal of Neuroscience, vol. 19, no. 7, pp. 1699-1707, 2004.

[19] F. Kapczinski, B. N. Frey, A. C. Andreazza, M. KauerSant'Anna, Â. B. M. Cunha, and R. M. Post, "Increased 
oxidative stress as a mechanism for decreased BDNF levels in acute manic episodes," Revista Brasileira de Psiquiatria, vol. 30, no. 3, pp. 243-245, 2008.

[20] A. Kumaran, C. C. Ho, and L. S. Hwang, "Protective effect of Nelumbo nucifera extracts on beta amyloid protein induced apoptosis in PC12 cells, in vitro model of Alzheimer's disease," Journal of Food and Drug Analysis, vol. 26, no. 1, pp. 172-181, 2018.

[21] Y. Liu, P. Chaturvedi, J. Fu, Q. Cai, W. Weckwerth, and P. Yang, "Induction and quantitative proteomic analysis of cell dedifferentiation during callus formation of lotus (Nelumbo nucifera Gaertn.spp. baijianlian)," Journal of Proteomics, vol. 131, pp. 61-70, 2016.

[22] D. Mastroiacovo, C. Kwik-Uribe, D. Grassi et al., "Cocoa flavanol consumption improves cognitive function, blood pressure control, and metabolic profile in elderly subjects: the Cocoa, Cognition, and Aging (CoCoA) Study-a randomized controlled trial," The American Journal of Clinical Nutrition, vol. 101, no. 3, pp. 538-548, 2015.

[23] A. H. Shinichi Kuriyama, K. Ohmori, T. Shimazu et al., "Green tea consumption and cognitive function: a cross-sectional study from the Tsurugaya Project," The American Journal of Clinical Nutrition, vol. 83, no. 2, pp. 355-361, 2006.

[24] Z. Zhang, X. Liu, J. P. Schroeder et al., "7,8-dihydroxyflavone prevents synaptic loss and memory deficits in a mouse model of Alzheimer's disease," Neuropsychopharmacology, vol. 39, no. 3, pp. 638-650, 2014.

[25] J. S. Xiao, B. J. Xie, Y. P. Cao, H. Wu, Z. D. Sun, and D. Xiao, "Characterization of oligomeric procyanidins and identification of quercetin glucuronide from lotus ( Nelumbo nucifera Gaertn.) seedpod," Journal of Agricultural and Food Chemistry, vol. 60, no. 11, pp. 2825-2829, 2012.

[26] J. Xu, S. Rong, B. Xie et al., "Memory impairment in cognitively impaired aged rats associated with decreased hippocampal CREB phosphorylation: reversal by procyanidins extracted from the lotus seedpod," The Journals of Gerontology Series A, vol. 65A, no. 9, pp. 933-940, 2010.

[27] J. Xu, S. Rong, B. Xie et al., "Procyanidins extracted from the lotus seedpod ameliorate age-related antioxidant deficit in aged rats," The Journals of Gerontology Series A, vol. 65A, no. 3, pp. 236-241, 2010.

[28] G. X. Mao, L. D. Zheng, Y. B. Cao et al., "Antiaging effect of pine pollen in human diploid fibroblasts and in a mouse model induced by D-galactose," Oxidative Medicine and Cellular Longevity, vol. 2012, Article ID 750963, 10 pages, 2012.

[29] Y. Gao, J. Chen, K. Li et al., "Replacement of Oct4 by Tet1 during iPSC induction reveals an important role of DNA methylation and hydroxymethylation in reprogramming," Cell Stem Cell, vol. 12, no. 4, pp. 453-469, 2013.

[30] D. Achaintre, A. Buleté, C. Cren-Olivé, L. Li, S. Rinaldi, and A. Scalbert, "Differential isotope labeling of 38 dietary polyphenols and their quantification in urine by liquid chromatography electrospray ionization tandem mass spectrometry," Analytical Chemistry, vol. 88, no. 5, pp. 2637-2644, 2016.

[31] Q. Wu, S. Li, X. Li et al., "Inhibition of advanced glycation endproduct formation by lotus seedpod oligomeric procyanidins through RAGE-MAPK signaling and NF- $\kappa$ B activation in high-fat-diet rats," Journal of Agricultural and Food Chemistry, vol. 63, no. 31, pp. 6989-6998, 2015.

[32] M. Urpi-Sarda, M. Monagas, N. Khan et al., "Targeted metabolic profiling of phenolics in urine and plasma after regular consumption of cocoa by liquid chromatography-tandem mass spectrometry," Journal of Chromatography. A, vol. 1216, no. 43, pp. 7258-7267, 2009.

[33] F. You, Q. Li, G. Jin, Y. Zheng, J. Chen, and H. Yang, "Genistein protects against $\mathrm{A} \beta_{25-35}$ induced apoptosis of PC12 cells through JNK signaling and modulation of Bcl-2 family messengers," BMC Neuroscience, vol. 18, no. 1, p. 12, 2017.

[34] G. Perry, A. D. Cash, and M. A. Smith, "Alzheimer disease and oxidative stress," Journal of Biomedicine \& Biotechnology, vol. 2, no. 3, 123 pages, 2002.

[35] S. Y. Park and D. S. Kim, "Discovery of natural products from Curcuma longa that protect cells from beta-amyloid insult: a drug discovery effort against Alzheimer's disease," Journal of Natural Products, vol. 65, no. 9, pp. 1227-1231, 2002.

[36] S. Y. Lee, J. W. Lee, H. Lee et al., "Inhibitory effect of green tea extract on $\beta$-amyloid-induced PC12 cell death by inhibition of the activation of NF- $\kappa \mathrm{B}$ and ERK/p38 MAP kinase pathway through antioxidant mechanisms," Brain Research. Molecular Brain Research, vol. 140, no. 1-2, pp. 45-54, 2005.

[37] Q. Wu, S. Li, X. Li et al., "A significant inhibitory effect on advanced glycation end product formation by catechin as the major metabolite of lotus seedpod oligomeric procyanidins," Nutrients, vol. 6, no. 8, pp. 3230-3244, 2014.

[38] C. F. Skibola and M. T. Smith, "Potential health impacts of excessive flavonoid intake," Free Radical Biology \& Medicine, vol. 29, no. 3-4, pp. 375-383, 2000.

[39] F. Puiggròs, N. Llópiz, A. Ardévol, C. Bladé, L. Arola, and M. Josepa Salvadó, "Grape seed procyanidins prevent oxidative injury by modulating the expression of antioxidant enzyme systems," Journal of Agricultural and Food Chemistry, vol. 53, no. 15, pp. 6080-6086, 2005.

[40] C. S. Yang, X. Wang, G. Lu, and S. C. Picinich, "Cancer prevention by tea: animal studies, molecular mechanisms and human relevance," Nature Reviews. Cancer, vol. 9, no. 6, pp. 429-439, 2009.

[41] R. M. van Dam, N. Naidoo, and R. Landberg, "Dietary flavonoids and the development of type 2 diabetes and cardiovascular diseases: review of recent findings," Current Opinion in Lipidology, vol. 24, no. 1, pp. 25-33, 2013.

[42] F. Perez-Vizcaino and J. Duarte, "Flavonols and cardiovascular disease," Molecular Aspects of Medicine, vol. 31, no. 6, pp. 478494, 2010.

[43] R. Meeusen, "Exercise, nutrition and the brain," Sports Medicine, vol. 44, Supplement 1, pp. 47-56, 2014.

[44] Y. R. Wang, Q. H. Wang, T. Zhang et al., "Associations between hepatic functions and plasma amyloid-beta levelsimplications for the capacity of liver in peripheral amyloidbeta clearance," Molecular Neurobiology, vol. 54, no. 3, pp. 2338-2344, 2017.

[45] Y. H. Liu, Y. R. Wang, Y. Xiang et al., "Clearance of amyloidbeta in Alzheimer's disease: shifting the action site from center to periphery," Molecular Neurobiology, vol. 51, no. 1, pp. 1-7, 2015.

[46] S. L. Seliger, "Moderate renal impairment and risk of dementia among older adults: the cardiovascular health cognition study," Journal of the American Society of Nephrology, vol. 15, no. 7, pp. 1904-1911, 2004.

[47] J. Wang, L. Ho, W. Zhao et al., "Grape-derived polyphenolics prevent Abeta oligomerization and attenuate cognitive deterioration in a mouse model of Alzheimer's disease," The Journal of Neuroscience, vol. 28, no. 25, pp. 6388-6392, 2008. 
[48] T. Hamaguchi, K. Ono, A. Murase, and M. Yamada, "Phenolic compounds prevent Alzheimer's pathology through different effects on the amyloid-beta aggregation pathway," The American Journal of Pathology, vol. 175, no. 6, pp. 2557-2565, 2009.

[49] X. Zhang, J. Hu, L. Zhong et al., "Quercetin stabilizes apolipoprotein $\mathrm{E}$ and reduces brain $\mathrm{A} \beta$ levels in amyloid model mice," Neuropharmacology, vol. 108, pp. 179-192, 2016.

[50] J. Lin, J. Yu, J. Zhao et al., "Fucoxanthin, a marine carotenoid, attenuates $\beta$-amyloid oligomer-induced neurotoxicity possibly via regulating the PI3K/Akt and the ERK pathways in SH-SY5Y cells," Oxidative Medicine and Cellular Longevity, vol. 2017, Article ID 6792543, 10 pages, 2017.

[51] B. T. Hyman, "Caspase activation without apoptosis: insight into $\mathrm{A} \beta$ initiation of neurodegeneration," Nature Neuroscience, vol. 14, no. 1, pp. 5-6, 2011.

[52] A. Sen, T. J. Nelson, and D. L. Alkon, "ApoE4 and A $\beta$ oligomers reduce BDNF expression via HDAC nuclear translocation," The Journal of Neuroscience, vol. 35, no. 19, pp. 7538-7551, 2015.

[53] E. Rosa and M. Fahnestock, "CREB expression mediates amyloid $\beta$-induced basal BDNF downregulation," Neurobiology of Aging, vol. 36, no. 8, pp. 2406-2413, 2015.

[54] B. Lu, G. Nagappan, X. Guan, P. J. Nathan, and P. Wren, "BDNF-based synaptic repair as a disease-modifying strategy for neurodegenerative diseases," Nature Reviews Neuroscience, vol. 14, no. 6, pp. 401-416, 2013.

[55] S. S. Valvassori, C. O. Arent, A. V. Steckert et al., "Intracerebral administration of BDNF protects rat brain against oxidative stress induced by ouabain in an animal model of mania," Molecular Neurobiology, vol. 52, no. 1, pp. 353-362, 2015.

[56] A. E. Roher, C. L. Esh, T. A. Kokjohn et al., “Amyloid beta peptides in human plasma and tissues and their significance for Alzheimer's disease," Alzheimers Dement, vol. 5, no. 1, pp. 18-29, 2009.

[57] J. Wang, B. J. Gu, C. L. Masters, and Y. J. Wang, "A systemic view of Alzheimer disease - insights from amyloid- $\beta$ metabolism beyond the brain," Nature Reviews Neurology, vol. 13, no. 10, pp. 612-623, 2017.

[58] S. M. de la Monte, "Type 3 diabetes is sporadic Alzheimer's disease: mini-review," European Neuropsychopharmacology, vol. 24, no. 12, pp. 1954-1960, 2014.

[59] C. Jiang, G. Li, P. Huang, Z. Liu, and B. Zhao, "The gut microbiota and Alzheimer's disease," Journal of Alzheimer's Disease, vol. 58, no. 1, pp. 1-15, 2017.

[60] L. Ho, M. G. Ferruzzi, E. M. Janle et al., "Identification of brain-targeted bioactive dietary quercetin-3-O-glucuronide as a novel intervention for Alzheimer's disease," The FASEB Journal, vol. 27, no. 2, pp. 769-781, 2013.

[61] A. Ishisaka, R. Mukai, J. Terao, N. Shibata, and Y. Kawai, "Specific localization of quercetin-3-O-glucuronide in human brain," Archives of Biochemistry and Biophysics, vol. 557, pp. 11-17, 2014.

[62] A. Ishisaka, S. Ichikawa, H. Sakakibara et al., "Accumulation of orally administered quercetin in brain tissue and its antioxidative effects in rats," Free Radical Biology \& Medicine, vol. 51, no. 7, pp. 1329-1336, 2011.

[63] S. Baral, R. Pariyar, J. Kim, H. S. Lee, and J. Seo, "Quercetin-3$\mathrm{O}$-glucuronide promotes the proliferation and migration of neural stem cells," Neurobiology of Aging, vol. 52, pp. 39-52, 2017.
[64] A. Serra, A. Macià, M. P. Romero, N. Anglès, J. R. Morelló, and M. J. Motilva, "Distribution of procyanidins and their metabolites in rat plasma and tissues after an acute intake of hazelnut extract," Food \& Function, vol. 2, no. 9, pp. 562-568, 2011.

[65] M. J. Kim, A. R. Seong, J. Y. Yoo et al., "Gallic acid, a histone acetyltransferase inhibitor, suppresses $\beta$-amyloid neurotoxicity by inhibiting microglial-mediated neuroinflammation," Molecular Nutrition \& Food Research, vol. 55, no. 12, pp. 1798-1808, 2011.

[66] F. U. Amin, S. A. Shah, and M. O. Kim, "Vanillic acid attenuates $\mathrm{A} \beta_{1-42}$-induced oxidative stress and cognitive impairment in mice," Scientific Reports, vol. 7, no. 1, article 40753, 2017.

[67] Y. Song, T. Cui, N. Xie, X. Zhang, Z. Qian, and J. Liu, "Protocatechuic acid improves cognitive deficits and attenuates amyloid deposits, inflammatory response in aged $\mathrm{A} \beta \mathrm{PP} / \mathrm{PS} 1$ double transgenic mice," International Immunopharmacology, vol. 20, no. 1, pp. 276-281, 2014. 


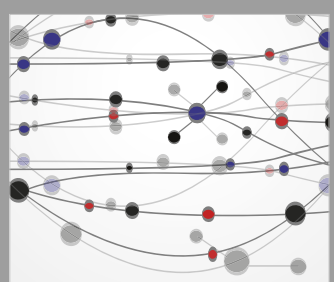

The Scientific World Journal
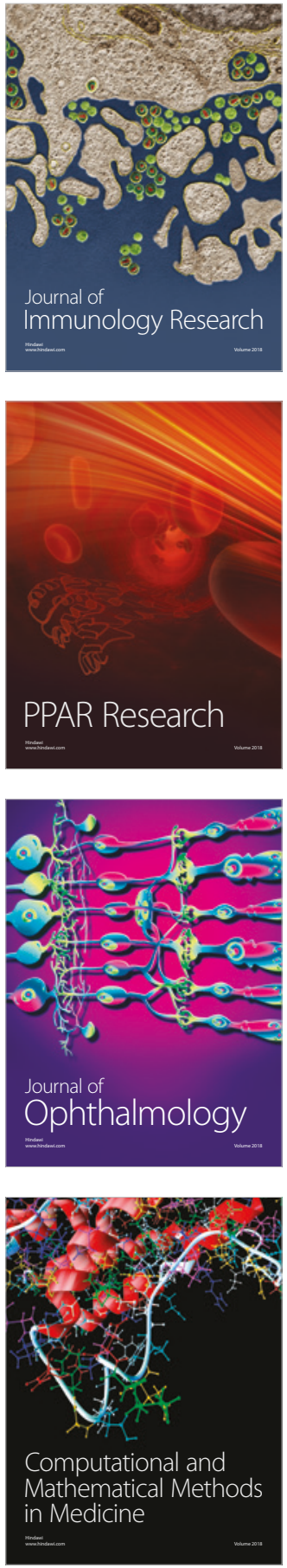

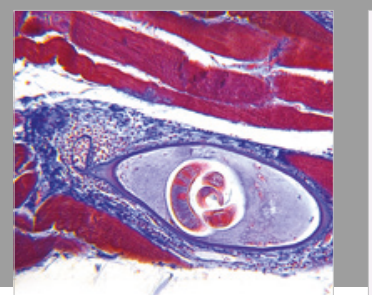

Gastroenterology Research and Practice

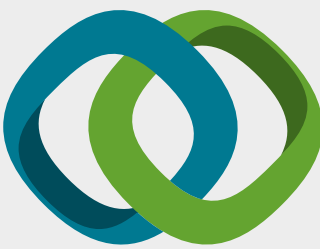

\section{Hindawi}

Submit your manuscripts at

www.hindawi.com
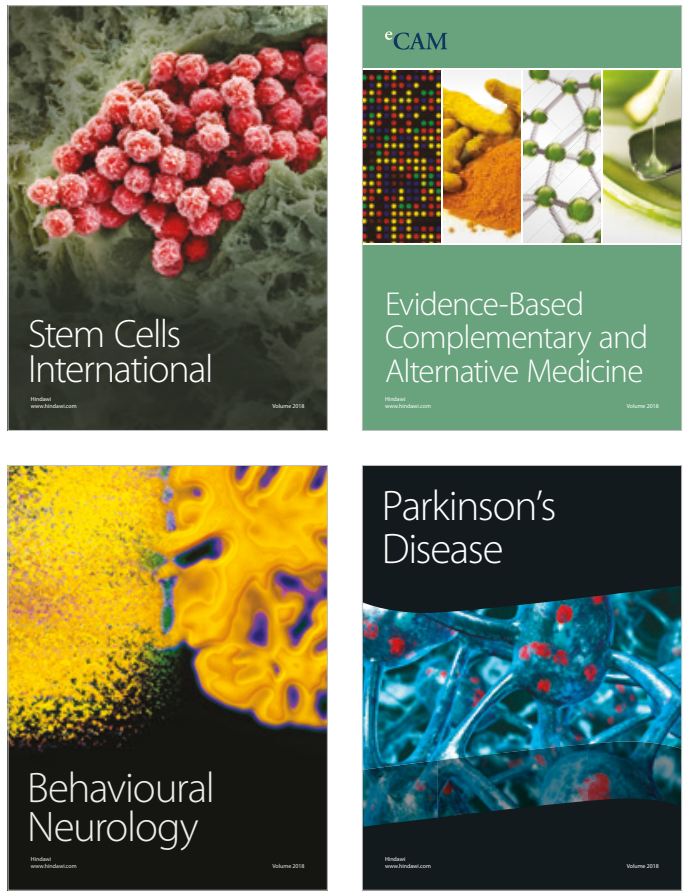

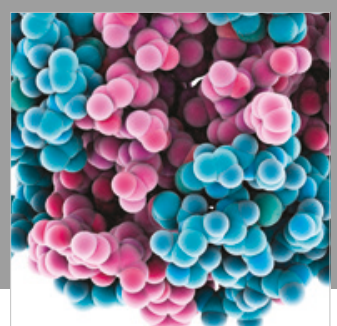

ournal of

Diabetes Research

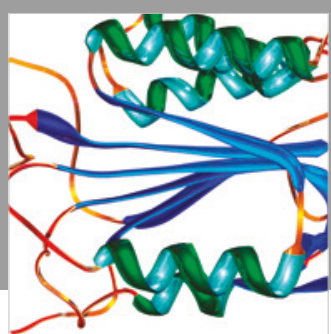

Disease Markers
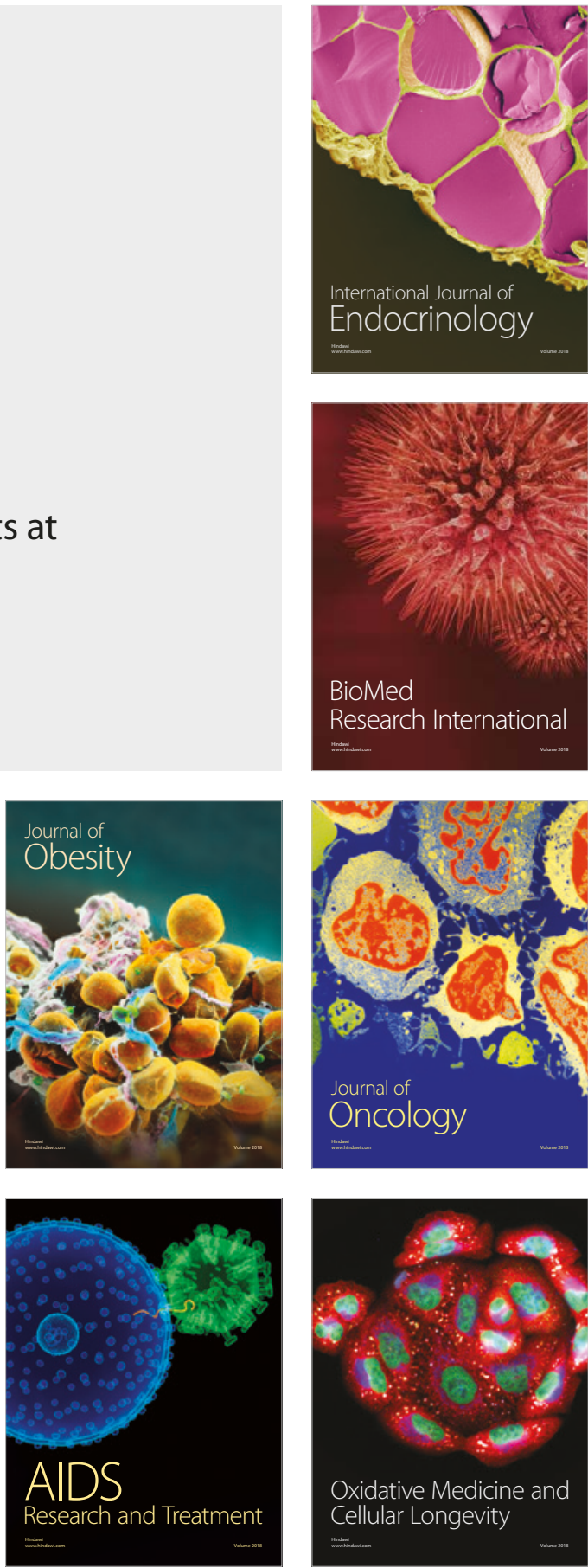